\title{
Radiometric dating of sediment records in European mountain lakes
}

\author{
Peter G. APPLEBY* \\ Department of Mathematical Sciences, University of Liverpool, PO Box 147, Liverpool L69 3BX, UK \\ *e-mail corresponding author: appleby@liverpool.ac.uk
}

\begin{abstract}
Sediment cores from seven European mountain lakes collected as part of a study of palaeolimnogical records of climate change (the MOLAR project) were dated radiometrically by ${ }^{210} \mathrm{~Pb}$. In spite of the remote locations, only one site recorded more or less uniform sediment accumulation throughout the past 150 years. At three further sites the ${ }^{210} \mathrm{~Pb}$ record indicated uniform sedimentation up until ca 1950 but significant increases since then. Stratigraphic dates based on records of fallout ${ }^{137} \mathrm{Cs}$ and ${ }^{241} \mathrm{Am}$ showed that ${ }^{210} \mathrm{~Pb}$ supply rates to these core sites had nonetheless remained relatively constant and that the sediments could be dated by the CRS model. At the remaining sites there were indications of episodic changes in both sedimentation rates and ${ }^{210} \mathrm{~Pb}$ supply rates. Since the changes were not in proportion, neither of the simple dating models (CRS or CIC) was applicable. Using the ${ }^{137} \mathrm{Cs}$ and ${ }^{241} \mathrm{Am}$ stratigraphic dates as reference points it was however possible to construct a realistic chronology for these cores by applying the CRS model piecewise to each time-bounded section.
\end{abstract}

Key words: sediment records, mountain lakes, ${ }^{210} \mathrm{~Pb}$ dating, artificial radionuclides

\section{INTRODUCTION}

One of the main aims of the recent European MOLAR project (Battarbee et al. 2000) was to assess the relationship between direct instrumental records of climate change and natural environmental records stored in remote mountain and arctic lake sediment sequences. Such lakes are thought to be particularly sensitive to climate change, and their sediments are expected to contain a range of physical, chemical and biological records of the response of the ecosystem to these changes. At each study site, climate records for the period 1781 to 1997 have been reconstructed using long term meteorological data from lowland observatories and models of the relationship between low and high altitude stations (Agusti-Panareda \& Thompson 2000). In order to investigate the relationship between climate records and sediment records, it was essential to determine a reliable chronology for sediments spanning this period.

The principal method for dating the MOLAR sites was ${ }^{210} \mathrm{~Pb}$ supported by chronostratigraphic dates based on records of the artificial radionuclides ${ }^{137} \mathrm{Cs}$ and ${ }^{241} \mathrm{Am}$. Following the introduction of the technique by Goldberg (1963) and Krishnaswami et al. (1971), ${ }^{210} \mathrm{~Pb}$ has become established as one of the standard tools for dating lake sediments spanning the past 100-150 years. The method is unequivocal at sites where sediment accumulation rates have remained relatively uniform throughout this period. At such sites concentrations of the unsupported (atmospherically supplied) component of total ${ }^{210} \mathrm{~Pb}$ activity decline exponentially with depth at a rate that is inversely proportional to the sedimentation rate. However, at sites impacted by natural and/or anthropogenic environmental change, sedimentation rates may well have varied in recent times, causing significant deviations of the ${ }^{210} \mathrm{~Pb}$ unsupported concentration versus depth profile from a simple exponential relationship. Different models have been developed to account for such deviations (Appleby \& Oldfield 1978; Robbins 1978) and the accuracy of ${ }^{210} \mathrm{~Pb}$ dates in a particular application will depend on the validity of the model used. This is usually done by reference to independent records of artificial fallout radionuclides such as ${ }^{137} \mathrm{Cs}$ (Pennington et al. 1973) and ${ }^{241}$ Am (Appleby et al. 1991) from the atmospheric testing of nuclear weapons, or from the 1986 Chernobyl reactor accident. A number of techniques for assessing ${ }^{210} \mathrm{~Pb}$ data and calculating a best chronology are given in the literature (e.g. Appleby \& Oldfield 1983; Oldfield \& Appleby 1984; Appleby 1998). One of the key aspects of the ${ }^{210} \mathrm{~Pb}$ dating methodology is an assessment of the dominant processes by which fallout is delivered to the core site. A potential problem in dating mountain lakes is the possible impact of seasonal effects on the uniformity of supply rates. During winter the water column is isolated from the natural atmospheric ${ }^{210} \mathrm{~Pb}$ flux. Fallout onto the lake and its catchment during this period is locked up in snow and ice and released only at the time of the spring thaw.

The main objective of this paper is to present a detailed sediment chronology for each of the MOLAR sites that takes account of the different transport processes. Since at most sites the ${ }^{210} \mathrm{~Pb}$ time-span was limited to no more than about 150 years, it was also important to determine a reliable means for extrapolating ${ }^{210} \mathrm{~Pb}$ dates back to 1781 , the beginning of the period of climate reconstruction. 


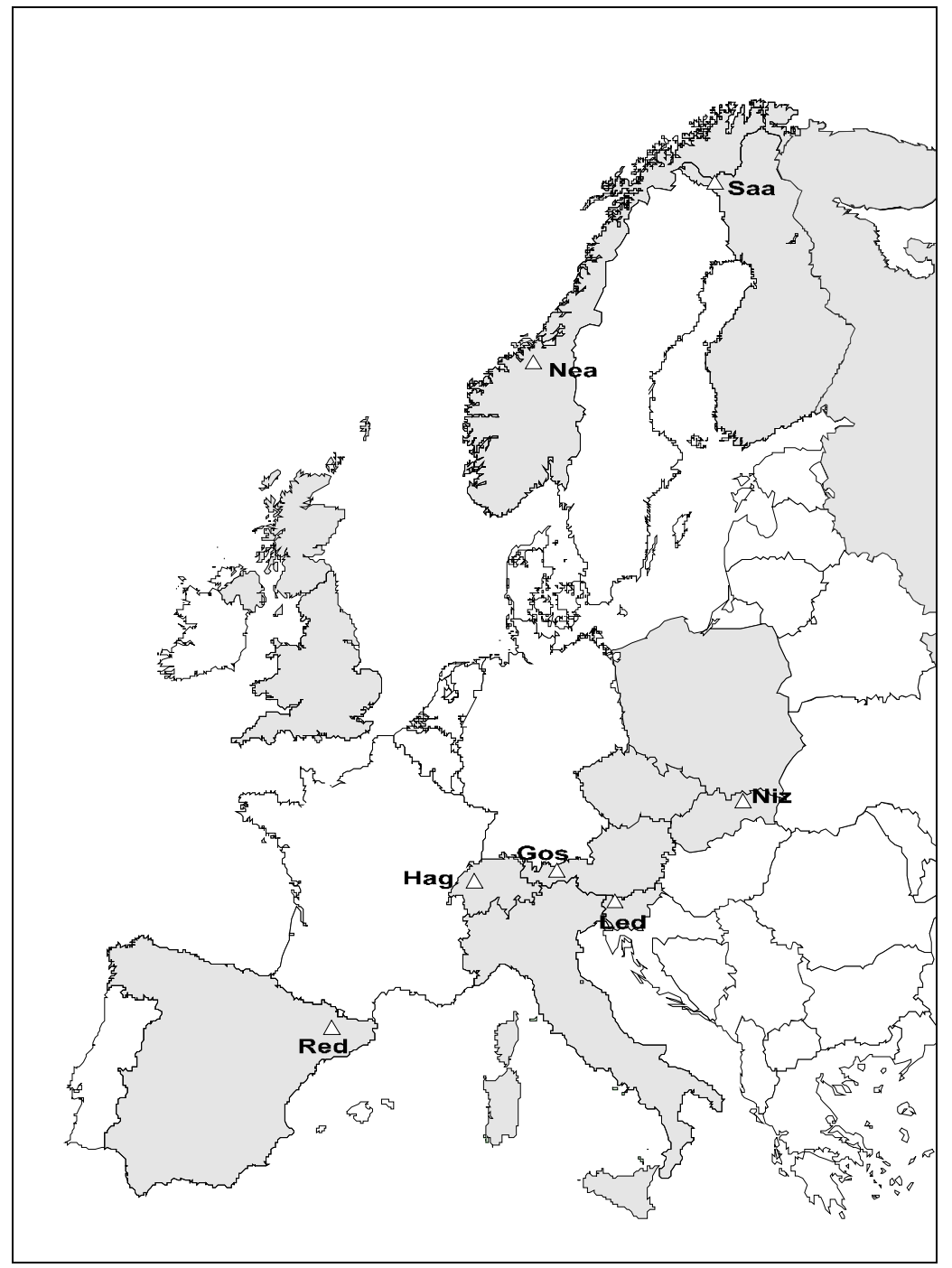

Fig. 1. Map of the Molar sites showing the locations of Saanajärvi, Øvre Neådalsvatn, Nižné Terianske Pleso, Gossenköllsee, Hagelsee, Ledvicah and Redó.

Tab. 1. The study sites and their main physiographic parameters.

\begin{tabular}{lccccccccc}
\hline & Latitude & Longitude & Altitude & $\begin{array}{c}\text { Mean Annual } \\
\text { Rainfall } \\
\mathrm{mm} \mathrm{y}^{-1}\end{array}$ & \multicolumn{2}{c}{ Catch area Lake area Max depth Mean depth } & \multicolumn{2}{c}{$\begin{array}{c}\text { Master (dated) } \\
\text { core }\end{array}$} \\
\hline Saanajärvi & $6^{\circ} 09^{\prime} \mathrm{N}$ & $20^{\circ} 52^{\prime} \mathrm{E}$ & 679 & 422 & 4.6 & 70 & 24 & 5.1 & SJ96/4 \\
Øvre Neådalsvatn & $62^{\circ} 46^{\prime} \mathrm{N}$ & $9^{\circ} \mathrm{E}$ & 728 & 1500 & 16 & 50 & 18 & 3.9 & OVNE4 \\
Nižné Terianske & $49^{\circ} 1^{\prime} \mathrm{N}$ & $20^{\circ} \mathrm{E}$ & 1941 & 1775 & 1.1 & 4.8 & 44.4 & 18.4 & TERI7 \\
Gossenköllesee & $47^{\circ} 13^{\prime} \mathrm{N}$ & $11^{\circ} 1^{\prime} \mathrm{E}$ & 2417 & 1300 & 0.2 & 1.7 & 9.9 & 4.6 & GKS2 \\
Hagelsee & $46^{\circ} 40^{\prime} \mathrm{N}$ & $8^{\circ} 2^{\prime} \mathrm{E}$ & 2339 & 1820 & 0.36 & 3 & 18.5 & 8.3 & HAG96-1 \\
Jezero v Ledvicah & $46^{\circ} 20^{\prime} \mathrm{N}$ & $13^{\circ} 47^{\prime} \mathrm{E}$ & 1830 & 2619 & $\sim 2.5$ & 2.4 & 15 & 5.7 & LEDV5 \\
Redó & $42^{\circ} 39^{\prime} \mathrm{N}$ & $0^{\circ} 46^{\prime} \mathrm{E}$ & 2240 & 1328 & 1.55 & 24 & 73 & 32 & RCM2 \\
\hline
\end{tabular}

\section{STUDY SITES}

The criteria governing the selection of the study sites were that they should be above the regional timberline, and have been subject to minimal human disturbance. At such sites there should be two main external forces driving ecological changes, climate change and atmospheric pollution. In order to distinguish the effects of these two factors the program included a wide range of sites in different environmental settings and varying de- grees of exposure to pollution. Their locations, shown in Figure 1, ranged from Finnish Lapland (Saanajärvi, $69^{\circ}$ $5^{\prime} \mathrm{N}, 20^{\circ} 52^{\prime} \mathrm{E}$ ) to the Spanish Pyrenees (Redó $42^{\circ} 39^{\prime}$ $\left.\mathrm{N}, 0^{\circ} 46^{\prime} \mathrm{E}\right)$. The main physiographic parameters of each site are given in table 1 .

\section{METHODS}

A number of sediment cores were collected from each site using the methods detailed in Wathne et al. (1995). One of these, designated the master core for that 
site (see Tab. 1), was used for radiometric dating. Dates from the master cores were transferred to other cores using depth correlations based on loss of ignition and other sediment data (Thompson \& Clark 1989).

Each master core was sectioned at intervals ranging from $0.15-0.25 \mathrm{~cm}$. Sub-samples of dried sediment were sent to the University of Liverpool Environmental Radioactivity Research Centre where they were analysed for ${ }^{210} \mathrm{~Pb},{ }^{226} \mathrm{Ra},{ }^{137} \mathrm{Cs}$ and ${ }^{241} \mathrm{Am}$ by direct gamma assay using Ortec HPGe GWL series well-type coaxial low background intrinsic germanium detectors (Appleby et al. 1986). ${ }^{210} \mathrm{~Pb}$ was determined via its gamma emissions at $46.5 \mathrm{keV}$, and ${ }^{226} \mathrm{Ra}$ by the $295 \mathrm{keV}$ and 352 $\mathrm{keV} \gamma$-rays emitted by its daughter isotope ${ }^{214} \mathrm{~Pb}$ following 3 weeks storage in sealed containers to allow radioactive equilibration. ${ }^{137} \mathrm{Cs}$ and ${ }^{241} \mathrm{Am}$ were measured by their emissions at $662 \mathrm{keV}$ and $59.5 \mathrm{keV}$ respectively. The absolute efficiencies of the detectors were determined using calibrated sources and sediment samples of known activity. Corrections were made for the effect of self-absorption of low energy $\gamma$-rays within the sample (Appleby et al. 1992).

Supported ${ }^{210} \mathrm{~Pb}$ in each sample was assumed to be in equilibrium with the in situ ${ }^{226} \mathrm{Ra}$, and unsupported ${ }^{210} \mathrm{~Pb}$ was calculated by subtracting ${ }^{226} \mathrm{Ra}$ activity from total ${ }^{210} \mathrm{~Pb}$. Radiometric dates were calculated from the ${ }^{210} \mathrm{~Pb}$ and ${ }^{137} \mathrm{Cs}$ records using the procedures described in Appleby (1998). Standard errors in the dates determined by uncertainties in the measured data were calculated using the methods described in Appleby (2000).

\section{RESULTS}

The results of the radiometric analyses are shown in figures 2-4. Detailed chronologies for each core are given in tables 2-8. These tables also include extrapolated dates (shown in italics) below the ${ }^{210} \mathrm{~Pb}$ dating horizon back to the beginning of the climate record in 1781. The ${ }^{210} \mathrm{~Pb}$ dating horizon is the depth at which unsupported ${ }^{210} \mathrm{~Pb}$ activity falls below the limit of detection.

The sites can be placed in three categories, those with uniform sedimentation rates throughout the past 150 years (Fig. 2), those with increasing sedimentation rates during the past few decades (Fig. 3), and those with irregular changes over a longer period of time (Fig. 4).

\subsection{Sites with uniform sedimentation rates}

Only one site appears to have had uniform sedimentation throughout the past 150 years, Øvre Neådalsvatn (Norway). At this site equilibrium between total ${ }^{210} \mathrm{~Pb}$ activity and the supporting ${ }^{226} \mathrm{Ra}$ (corresponding to $c a 150$ years accumulation) was reached at a depth of $c a 9 \mathrm{~cm}$ (Fig. 2a). Supported ${ }^{210} \mathrm{~Pb}\left({ }^{226} \mathrm{Ra}\right)$ concentrations have been virtually constant throughout this period. Unsupported ${ }^{210} \mathrm{~Pb}$ concentrations (Fig. 2b) decline more or less exponentially with depth. In consequence, ${ }^{210} \mathrm{~Pb}$ dates calculated using the standard simple dating models (CRS and CIC) are unequivocal. Both indicate relatively uniform sedimentation since $c a 1860$, (a)

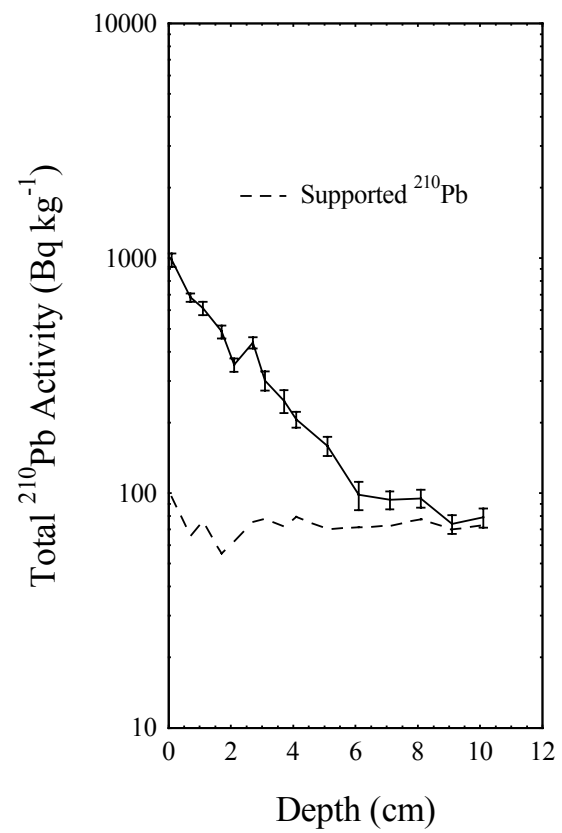

(b)

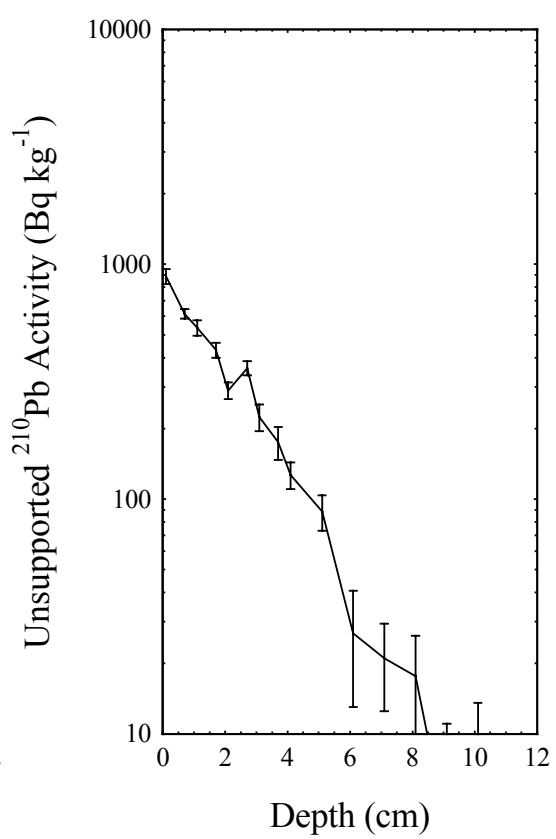

(c)

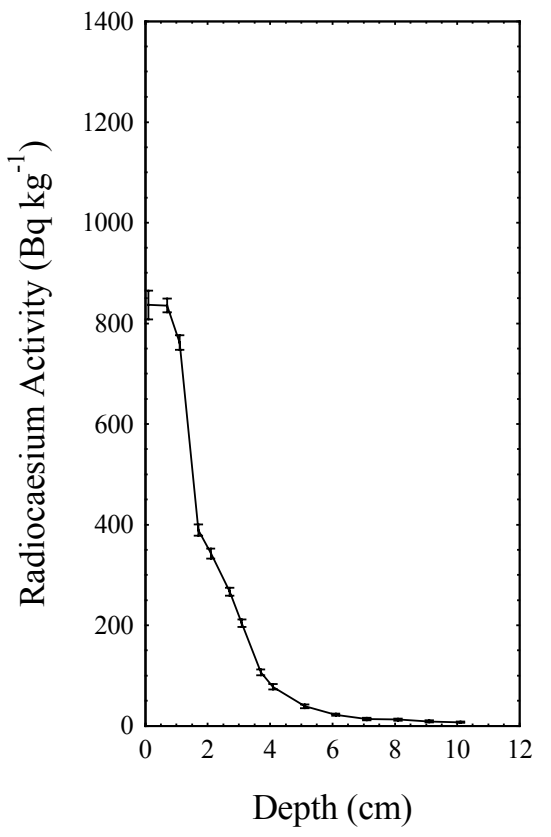

Fig. 2. Fallout radionuclides in Øvre Neådalsvatn core OVNE4 showing (a) total and supported ${ }^{210} \mathrm{~Pb}$, (b) unsupported ${ }^{210} \mathrm{~Pb}$, (c) ${ }^{137} \mathrm{Cs}$ and ${ }^{241} \mathrm{Am}$ activities versus depth in the core. 
with a mean value of $0.0100 \pm 0.0004 \mathrm{~g} \mathrm{~cm}^{-2} \mathrm{y}^{-1}$. Sediment dates for this core (OVRE4) have been calculated using the mean post-1860 sedimentation rate, and the results given in table 2 . Since small irregularities in the detailed sedimentation rates are probably not significant, these dates are probably more reliable than those given directly by the dating model. Differences between the two are however small ( $<4$ years).

The ${ }^{210} \mathrm{~Pb}$ chronology places 1963 at just over $2 \mathrm{~cm}$. The absence of a peak in ${ }^{137} \mathrm{Cs}$ concentrations at this depth recording maximum fallout from the atmospheric testing of nuclear weapons can be attributed to high levels of ${ }^{137} \mathrm{Cs}$ activity in the surficial sediments from the 1986 Chernobyl accident.

\subsection{Sites with recent increases in sedimentation rates}

At Saanajärvi (Finland), Gossenköllesee (Austria) and Redó (Spanish Pyrenees) the unsupported ${ }^{210} \mathrm{~Pb}$ depth profile was approximately exponential in the deeper parts of each core, suggesting uniform sedimentation in the earlier part of the record. In each case, however, there was a significant flattening of the profile in the upper sections (Figs 3(a)). Relatively well resolved ${ }^{137} \mathrm{Cs}$ and ${ }^{241} \mathrm{Am}$ peaks (Figs 3(b)) show that the surficial sediments are not subject a high degree of physical or biological mixing. The most likely cause of the changing ${ }^{210} \mathrm{~Pb}$ gradient is accelerating sedimentation. The ${ }^{137} \mathrm{Cs}$ and ${ }^{241} \mathrm{Am}$ stratigraphic dates can be used to resolve differences between the various ${ }^{210} \mathrm{~Pb}$

Tab. 2. ${ }^{210} \mathrm{~Pb}$ chronology of Øvre Neådalsvatn core OVNE4 (in italics extrapolated dates).

\begin{tabular}{|c|c|c|c|c|}
\hline \multirow{2}{*}{$\begin{array}{l}\text { Depth } \\
\mathrm{cm}\end{array}$} & \multicolumn{2}{|c|}{ Date } & \multicolumn{2}{|c|}{ Sedimentation rate } \\
\hline & $\mathrm{AD}$ & \pm & $\mathrm{g} \mathrm{cm}^{-2} \mathrm{y}^{-1}$ & $\mathrm{~cm} \mathrm{y}^{-1}$ \\
\hline 0.00 & 1996 & & & \\
\hline 0.20 & 1994 & 1 & & 0.079 \\
\hline 0.40 & 1991 & 1 & & 0.075 \\
\hline 0.60 & 1988 & 1 & & 0.071 \\
\hline 0.80 & 1985 & 1 & & 0.066 \\
\hline 1.00 & 1982 & 1 & & 0.061 \\
\hline 1.20 & 1979 & 1 & & 0.058 \\
\hline 1.40 & 1975 & 1 & & 0.056 \\
\hline 1.60 & 1972 & 1 & & 0.057 \\
\hline 1.80 & 1968 & 2 & & 0.059 \\
\hline 2.00 & 1965 & 2 & & 0.061 \\
\hline 2.20 & 1962 & 2 & & 0.062 \\
\hline 2.40 & 1958 & 2 & & 0.061 \\
\hline 2.60 & 1955 & 2 & & 0.060 \\
\hline 2.80 & 1952 & 2 & 0.010 & 0.058 \\
\hline 3.00 & 1948 & 2 & & 0.056 \\
\hline 3.20 & 1945 & 3 & & 0.055 \\
\hline 3.40 & 1941 & 3 & & 0.055 \\
\hline 3.60 & 1937 & 3 & & 0.057 \\
\hline 3.80 & 1934 & 3 & & 0.059 \\
\hline 4.00 & 1930 & 3 & & 0.061 \\
\hline 4.20 & 1927 & 3 & & 0.063 \\
\hline 4.40 & 1924 & 3 & & 0.064 \\
\hline 4.60 & 1921 & 3 & & 0.065 \\
\hline 4.80 & 1918 & 4 & & 0.064 \\
\hline 5.00 & 1915 & 4 & & 0.062 \\
\hline 5.20 & 1912 & 4 & & 0.061 \\
\hline 5.40 & 1908 & 4 & & 0.060 \\
\hline 5.60 & 1905 & 4 & & 0.059 \\
\hline 5.80 & 1901 & 4 & & 0.058 \\
\hline
\end{tabular}

\begin{tabular}{|c|c|c|c|c|}
\hline \multirow{2}{*}{$\begin{array}{l}\text { Depth } \\
\mathrm{cm}\end{array}$} & \multicolumn{2}{|c|}{ Date } & \multicolumn{2}{|c|}{ Sedimentation rate } \\
\hline & $\mathrm{AD}$ & \pm & $\mathrm{g} \mathrm{cm}^{-2} \mathrm{y}^{-1}$ & $\mathrm{~cm} \mathrm{y}^{-1}$ \\
\hline 6.00 & 1898 & 4 & & 0.056 \\
\hline 6.20 & 1894 & 5 & & 0.055 \\
\hline 6.40 & 1891 & 5 & & 0.053 \\
\hline 6.60 & 1887 & 5 & & 0.052 \\
\hline 6.80 & 1883 & 5 & & 0.052 \\
\hline 7.00 & 1879 & 5 & & 0.051 \\
\hline 7.20 & 1875 & 5 & & 0.050 \\
\hline 7.40 & 1871 & 5 & & 0.049 \\
\hline 7.60 & 1867 & 6 & & 0.049 \\
\hline 7.80 & 1863 & 6 & & 0.049 \\
\hline 8.00 & 1859 & 6 & & 0.048 \\
\hline 8.20 & 1855 & 7 & & 0.046 \\
\hline 8.40 & 1850 & 7 & & 0.045 \\
\hline 8.60 & 1846 & 7 & & 0.043 \\
\hline 8.80 & 1841 & 7 & 0.010 & 0.043 \\
\hline 9.00 & 1836 & 7 & & 0.044 \\
\hline 9.20 & 1832 & 8 & & 0.045 \\
\hline 9.40 & 1827 & 8 & & 0.046 \\
\hline 9.60 & 1823 & 8 & & 0.047 \\
\hline 9.80 & 1819 & 8 & & 0.049 \\
\hline 10.00 & 1815 & 8 & & 0.050 \\
\hline 10.20 & 1811 & 8 & & 0.052 \\
\hline 10.40 & 1807 & 9 & & 0.055 \\
\hline 10.60 & 1803 & 9 & & 0.057 \\
\hline 10.80 & 1800 & 9 & & 0.060 \\
\hline 11.00 & 1797 & 9 & & 0.062 \\
\hline 11.20 & 1794 & 9 & & 0.062 \\
\hline 11.40 & 1790 & 9 & & 0.060 \\
\hline 11.60 & 1787 & 9 & & 0.057 \\
\hline 11.80 & 1783 & 10 & & 0.057 \\
\hline
\end{tabular}

The results for OVRE4 (the master core) are virtually identical to those from two other cores from Øvre Neådalsvatn dated by ${ }^{210} \mathrm{~Pb}$. OVRE7, also collected in 1996 as part of the MOLAR project, had a mean sedimentation rate of $0.0102 \pm 0.0004 \mathrm{~g} \mathrm{~cm}^{-2} \mathrm{y}^{-1}$. OVRE1, collected in 1991 as part of the earlier AL:PE project had a mean sedimentation rate of $0.0098 \pm 0.0006 \mathrm{~g}$ $\mathrm{cm}^{-2} \mathrm{y}^{-1}$. In view of the apparent temporal and spatial stability of sediment accumulation in this lake, it would appear relatively safe to extrapolate the chronology of ØVRE4 back to ca1781, using the mean post-1860 sedimentation rate.

dating models resulting from these changes.

\subsubsection{Saanajärvi}

Equilibrium of total ${ }^{210} \mathrm{~Pb}$ activity with the supporting ${ }^{226} \mathrm{Ra}$ was reached at a depth of between 5-6 cm. In view of the high surficial ${ }^{210} \mathrm{~Pb}$ activity it is likely that this represents a period of about 150 years. Between $c a$ $2-5 \mathrm{~cm}$ the unsupported ${ }^{210} \mathrm{~Pb}$ versus depth profile is closely approximated by an exponential function. Above $\mathrm{ca} 2 \mathrm{~cm}$ there is a significant deviation from this relationship (Fig. 3i(a)). 
i(a)

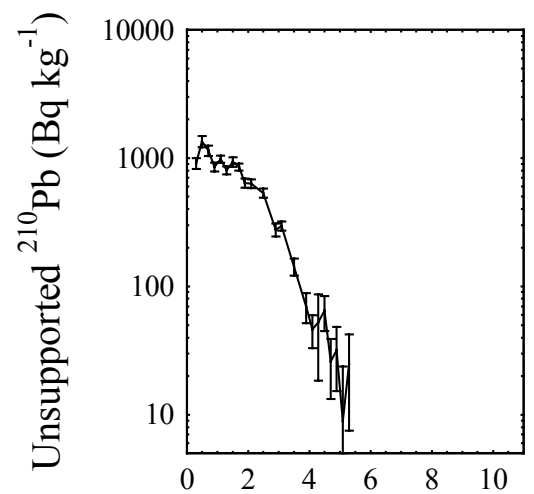

i(b)

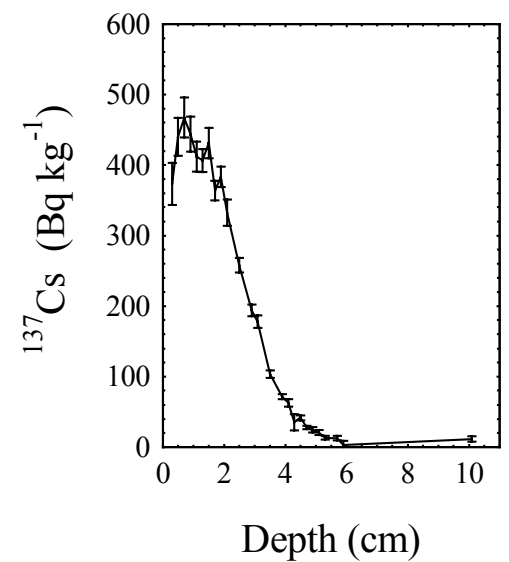

ii(a)

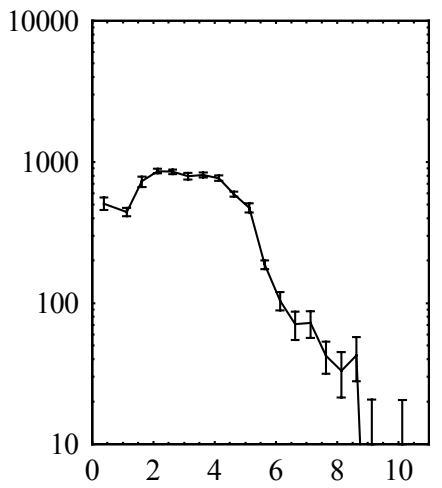

ii(b)

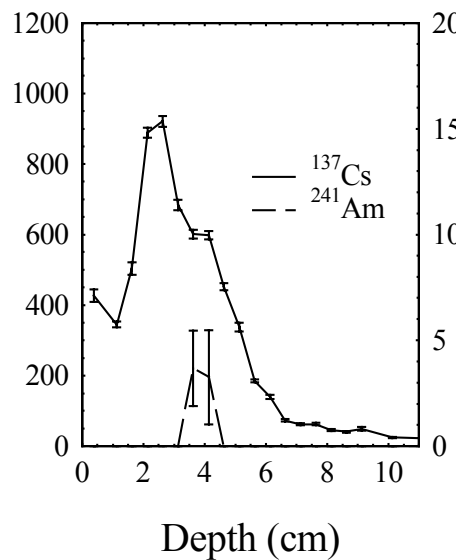

iii(a)

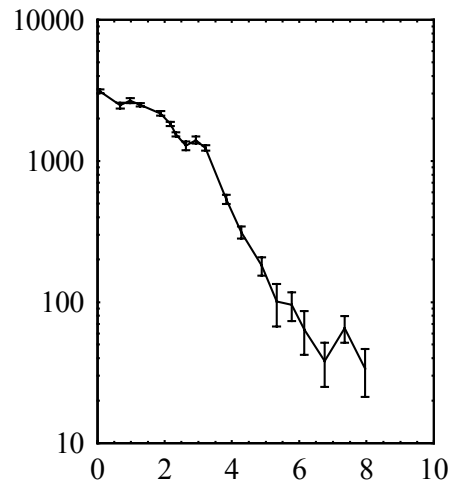

iii(b)

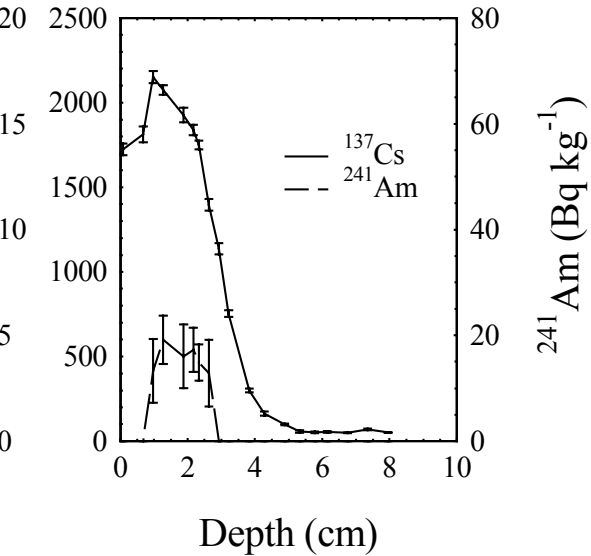

Fig. 3. Fallout radionuclides in (i) Saanajärvi, (ii) Gossenköllesee, (iii) Redó showing (a) unsupported ${ }^{210} \mathrm{~Pb}$ and (b) ${ }^{137} \mathrm{Cs}$ activities versus depth in the core. In each of these cores there is evidence of acceleration sedimentation rates in recent decades.

The ${ }^{137} \mathrm{Cs}$ activity versus depth profile (Fig. 3i(b)) has a well-resolved subsurface peak at $0.7 \mathrm{~cm}$ that both the standard ${ }^{210} \mathrm{~Pb}$ models (CRS and CIC) suggest is a record of fallout from the 1986 Chernobyl accident. Downward migration of Chernobyl ${ }^{137} \mathrm{Cs}$ may have partially obscured the weapons fallout record. The distribution of the ${ }^{137} \mathrm{Cs}$ inventory does however suggest that the period of maximum weapons fallout is a little above $2 \mathrm{~cm}$. The $\mathrm{CRS}{ }^{210} \mathrm{~Pb}$ dating model places 1963 at a depth of $1.7 \mathrm{~cm}$, very close to a small subsidiary ${ }^{137} \mathrm{Cs}$ peak at $1.5 \mathrm{~cm}$ that may record the 1963 fallout maximum. The apparent agreement suggests that ${ }^{210} \mathrm{~Pb}$ supply rates have not changed significantly in recent decades and that the CRS model should be applicable to the whole of the core. Calculations using this model (Tab. 3 ) show that sedimentation rates from the mid $19^{\text {th }}$ century through to $c a 1960$ were relatively stable, with a mean value of $0.012 \pm 0.001 \mathrm{~g} \mathrm{~cm}^{-2} \mathrm{y}^{-1}(0.024 \pm 0.002$ $\left.\mathrm{cm} \mathrm{y}^{-1}\right)$. Since then there has been a significant increase, and the mean sedimentation rate during the past 30 years is calculated to be $0.025 \pm 0.005 \mathrm{~g} \mathrm{~cm}^{-2} \mathrm{y}^{-1}(0.053$ $\left.\pm 0.010 \mathrm{~cm} \mathrm{y}^{-1}\right)$. Data near the base of the core suggest that sedimentation rates may have been a little lower in the mid $19^{\text {th }}$ century. Extrapolated dates below the base of the ${ }^{210} \mathrm{~Pb}$ record have been calculated using the estimated basal value of $0.0078 \mathrm{~g} \mathrm{~cm}^{-2} \mathrm{y}^{-1}$.

\subsubsection{Gossenköllesee}

From the equilibrium depth at $9 \mathrm{~cm}$, up to $c a 4.5 \mathrm{~cm}$, the unsupported ${ }^{210} \mathrm{~Pb}$ profile in this core more or less follows an exponential relation (Fig. 3ii(a)). At $4.5 \mathrm{~cm}$ there is however a very abrupt change. Activity is virtually constant from $4.5 \mathrm{~cm}$ through to $1.5 \mathrm{~cm}$, and even declines in the surficial sediments.

A well resolved peak in ${ }^{137} \mathrm{Cs}$ activity between 2.0 $2.75 \mathrm{~cm}$ (Fig. 3ii(b)) precludes sediment mixing as an explanation for the ${ }^{210} \mathrm{~Pb}$ record. The high ${ }^{137} \mathrm{Cs}$ concentrations in the peak together with evidence from soil cores in the catchment show that this feature almost certainly records fallout from the 1986 Chernobyl accident. A small peak in ${ }^{241} \mathrm{Am}$ activity at $3.5-4.25 \mathrm{~cm}$ coupled with a small shoulder on the ${ }^{137} \mathrm{Cs}$ profile identifies sediments at this depth as dating from $c a 1963$, the year of maximum fallout from the atmospheric testing 
Tab. 3. ${ }^{210} \mathrm{~Pb}$ chronology of Saanajärvi core SJ96/4 (in italics extrapolated dates).

\begin{tabular}{lcccc}
\hline $\begin{array}{l}\text { Depth } \\
\mathrm{cm}\end{array}$ & $\begin{array}{c}\text { Date } \\
\mathrm{AD}\end{array}$ & \pm & \multicolumn{2}{c}{ Sedimentation rate } \\
$\mathrm{g} \mathrm{cm}^{-2} \mathrm{y}^{-1}$ & $\mathrm{~cm} \mathrm{y}^{-1}$ \\
\hline 0.00 & 1996 & & & \\
0.20 & 1994 & 2 & 0.039 & 0.086 \\
0.40 & 1991 & 2 & 0.030 & 0.064 \\
0.60 & 1987 & 2 & 0.023 & 0.046 \\
0.80 & 1983 & 2 & 0.026 & 0.054 \\
1.00 & 1979 & 2 & 0.025 & 0.053 \\
1.20 & 1975 & 2 & 0.022 & 0.047 \\
1.40 & 1971 & 2 & 0.020 & 0.043 \\
1.60 & 1966 & 2 & 0.016 & 0.036 \\
1.80 & 1960 & 2 & 0.017 & 0.037 \\
2.00 & 1955 & 2 & 0.017 & 0.035 \\
2.20 & 1948 & 2 & 0.014 & 0.030 \\
2.40 & 1941 & 2 & 0.012 & 0.026 \\
2.60 & 1933 & 3 & 0.012 & 0.025 \\
2.80 & 1926 & 3 & 0.013 & 0.027 \\
\hline
\end{tabular}

\begin{tabular}{lcccc}
\hline $\begin{array}{l}\text { Depth } \\
\mathrm{cm}\end{array}$ & $\begin{array}{c}\text { Date } \\
\mathrm{AD}\end{array}$ & \pm & \multicolumn{2}{c}{ Sedimentation rate } \\
$\mathrm{g} \mathrm{cm}^{-2} \mathrm{y}^{-1}$ & $\mathrm{~cm} \mathrm{y}^{-1}$ \\
\hline 3.00 & 1917 & 3 & 0.012 & 0.024 \\
3.20 & 1909 & 4 & 0.010 & 0.021 \\
3.40 & 1899 & 5 & 0.011 & 0.022 \\
3.60 & 1890 & 7 & 0.012 & 0.024 \\
3.80 & 1883 & 8 & 0.013 & 0.027 \\
4.00 & 1875 & 10 & 0.016 & 0.030 \\
4.20 & 1868 & 12 & 0.015 & 0.025 \\
4.40 & 1857 & 15 & 0.0089 & 0.015 \\
4.60 & 1843 & 22 & 0.0083 & 0.016 \\
4.8 & 1831 & 27 & 0.0081 & 0.016 \\
5.0 & 1819 & 32 & 0.0078 & 0.016 \\
5.2 & 1806 & 32 & 0.0078 & 0.016 \\
5.4 & 1793 & 33 & 0.0078 & 0.016 \\
5.6 & 1781 & 34 & 0.0078 & 0.016 \\
& & & & \\
\hline
\end{tabular}

Tab. 4. ${ }^{210} \mathrm{~Pb}$ chronology of Gossenköllesee core GKS2 (in italics extrapolated dates).

\begin{tabular}{lcccc}
\hline $\begin{array}{l}\text { Depth } \\
\mathrm{cm}\end{array}$ & \multicolumn{2}{c}{ Date } & \multicolumn{2}{c}{ Sedimentation rate } \\
$\mathrm{g} \mathrm{cm} \mathrm{y}^{-2} \mathrm{y}^{-1}$ & \\
\hline 0.00 & $\mathrm{AD}$ & \pm & & \\
0.25 & 1996 & & & \\
0.50 & 1996 & 2 & 0.0132 & 0.450 \\
0.75 & 1995 & 2 & 0.0131 & 0.428 \\
1.00 & 1994 & 2 & 0.0134 & 0.412 \\
1.25 & 1994 & 2 & 0.0138 & 0.396 \\
1.50 & 1993 & 2 & 0.0125 & 0.339 \\
1.75 & 1992 & 2 & 0.0095 & 0.237 \\
2.00 & 1991 & 2 & 0.0075 & 0.169 \\
2.25 & 1989 & 2 & 0.0066 & 0.137 \\
2.50 & 1987 & 2 & 0.0059 & 0.114 \\
2.75 & 1985 & 2 & 0.0055 & 0.099 \\
3.00 & 1982 & 2 & 0.0052 & 0.089 \\
3.25 & 1979 & 2 & 0.0049 & 0.082 \\
3.50 & 1976 & 2 & 0.0045 & 0.075 \\
3.75 & 1972 & 2 & 0.0040 & 0.067 \\
4.00 & 1968 & 2 & 0.0035 & 0.058 \\
4.25 & 1964 & 2 & 0.0032 & 0.048 \\
4.50 & 1958 & 2 & 0.0028 & 0.041 \\
4.75 & 1951 & 2 & 0.0026 & 0.035 \\
5.00 & 1943 & 2 & 0.0023 & 0.030 \\
5.25 & 1934 & 2 & 0.0020 & 0.025 \\
\hline & 1925 & 2 & 0.0019 & 0.025 \\
\hline
\end{tabular}

\begin{tabular}{lcccc}
\hline \multirow{2}{*}{$\begin{array}{l}\text { Depth } \\
\mathrm{cm}\end{array}$} & \multicolumn{2}{c}{ Date } & \multicolumn{2}{c}{ Sedimentation rate } \\
& $\mathrm{AD}$ & \pm & $\mathrm{g} \mathrm{cm}^{-2} \mathrm{y}^{-1}$ & $\mathrm{~cm} \mathrm{y}^{-1}$ \\
\hline 5.50 & 1915 & 3 & 0.0022 & 0.029 \\
5.75 & 1906 & 3 & 0.0025 & 0.034 \\
6.00 & 1899 & 4 & 0.0027 & 0.040 \\
6.25 & 1893 & 4 & 0.0028 & 0.045 \\
6.50 & 1888 & 4 & 0.0029 & 0.051 \\
6.75 & 1883 & 5 & 0.0028 & 0.050 \\
7.00 & 1878 & 5 & 0.0024 & 0.043 \\
7.25 & 1872 & 6 & 0.0022 & 0.040 \\
7.50 & 1865 & 6 & 0.0022 & 0.041 \\
7.75 & 1859 & 7 & 0.0022 & 0.042 \\
8.00 & 1854 & 8 & 0.0022 & 0.044 \\
8.25 & 1848 & 9 & 0.0022 & 0.045 \\
8.50 & 1839 & 11 & 0.0022 & 0.044 \\
8.75 & 1837 & 11 & 0.0022 & 0.043 \\
9.00 & 1831 & 11 & 0.0022 & 0.041 \\
9.25 & 1825 & 11 & 0.0022 & 0.039 \\
9.50 & 1818 & 12 & 0.0022 & 0.036 \\
9.75 & 1811 & 12 & 0.0022 & 0.034 \\
10.00 & 1804 & 12 & 0.0022 & 0.033 \\
10.25 & 1796 & 13 & 0.0022 & 0.033 \\
10.50 & 1788 & 13 & 0.0022 & 0.034 \\
10.75 & 1781 & 14 & 0.0022 & 0.035 \\
\hline
\end{tabular}

of nuclear weapons. ${ }^{210} \mathrm{~Pb}$ dates calculated using the CRS dating model place 1986 at a depth of $2.25-2.5 \mathrm{~cm}$ and 1963 at a depth of $3.75-4.0 \mathrm{~cm}$, in excellent agreement with the ${ }^{137} \mathrm{Cs}$ and ${ }^{241} \mathrm{Am}$ dates. We again infer that the CRS model should be applicable to the whole core. Using this model, the transition at $4.5 \mathrm{~cm}$ is dated 1951. Before this time sedimentation rates appear to have been slow but relatively uniform for more than a century. The mean pre-1950 sedimentation rate is calculated to be $0.0022 \pm 0.0002 \mathrm{~g} \mathrm{~cm}^{-2} \mathrm{y}^{-1}\left(0.036 \mathrm{~cm} \mathrm{y}^{-1}\right)$. Since then sedimentation rates have increased dramatically, particularly during the past decade, though the present-day value of $c a 0.013 \mathrm{~g} \mathrm{~cm}^{-2} \mathrm{y}^{-1}$ is still only comparable to the long-term sedimentation rate in Øvre Neådalsvatn. The detailed results are given in table 4 . Extrapolated dates below the ${ }^{210} \mathrm{~Pb}$ dating horizon have

been calculated using the mean pre-1950 sedimentation rate.

\subsubsection{Redó}

The unsupported ${ }^{210} \mathrm{~Pb}$ activity versus depth profile (Fig. 3iii(a)) again has two distinct zones:

- an upper zone $(0-3 \mathrm{~cm})$ with a shallow ${ }^{210} \mathrm{~Pb}$ gradient and a number of minor irregularities;

- a deeper zone (3-7 cm) with a steeper ${ }^{210} \mathrm{~Pb}$ gradient in which unsupported activity declines more or less exponentially with depth.

Radioactive equilibrium is reached at a depth of about $9 \mathrm{~cm}$. Between $7-9 \mathrm{~cm}$ there is a small irregularity that may record a disturbance in the latter half of the $19^{\text {th }}$ century. 
Tab. 5. ${ }^{210} \mathrm{~Pb}$ chronology of Redó Lake core RCM2 (in italics extrapolated dates).

\begin{tabular}{|c|c|c|c|c|}
\hline \multirow{2}{*}{$\begin{array}{l}\text { Depth } \\
\mathrm{cm}\end{array}$} & \multicolumn{2}{|c|}{ Date } & \multicolumn{2}{|c|}{ Sedimentation rate } \\
\hline & $\mathrm{AD}$ & \pm & $\mathrm{g} \mathrm{cm}^{-2} \mathrm{y}^{-1}$ & $\mathrm{~cm} \mathrm{y}^{-1}$ \\
\hline 0.00 & 1997 & & & \\
\hline 0.15 & 1995 & 2 & 0.0099 & 0.097 \\
\hline 0.30 & 1994 & 2 & 0.0100 & 0.096 \\
\hline 0.45 & 1992 & 2 & 0.0101 & 0.096 \\
\hline 0.60 & 1991 & 2 & 0.0102 & 0.095 \\
\hline 0.75 & 1989 & 2 & 0.0098 & 0.089 \\
\hline 0.90 & 1987 & 2 & 0.0089 & 0.075 \\
\hline 1.05 & 1985 & 2 & 0.0082 & 0.066 \\
\hline 1.20 & 1983 & 2 & 0.0079 & 0.061 \\
\hline 1.35 & 1980 & 2 & 0.0076 & 0.057 \\
\hline 1.50 & 1977 & 2 & 0.0072 & 0.054 \\
\hline 1.65 & 1974 & 2 & 0.0068 & 0.051 \\
\hline 1.80 & 1971 & 2 & 0.0064 & 0.047 \\
\hline 1.95 & 1968 & 2 & 0.0062 & 0.045 \\
\hline 2.10 & 1965 & 2 & 0.0061 & 0.044 \\
\hline 2.25 & 1962 & 2 & 0.0062 & 0.044 \\
\hline 2.40 & 1958 & 2 & 0.0063 & 0.045 \\
\hline 2.55 & 1955 & 2 & 0.0063 & 0.045 \\
\hline 2.70 & 1951 & 2 & 0.0058 & 0.042 \\
\hline 2.85 & 1947 & 2 & 0.0049 & 0.036 \\
\hline 3.00 & 1943 & 2 & 0.0043 & 0.032 \\
\hline 3.15 & 1938 & 2 & 0.0039 & 0.030 \\
\hline 3.30 & 1933 & 2 & 0.0039 & 0.030 \\
\hline 3.45 & 1929 & 2 & 0.0042 & 0.032 \\
\hline 3.60 & 1924 & 2 & 0.0045 & 0.034 \\
\hline
\end{tabular}

\begin{tabular}{|c|c|c|c|c|}
\hline \multirow{2}{*}{$\begin{array}{l}\text { Depth } \\
\mathrm{cm}\end{array}$} & \multicolumn{2}{|c|}{ Date } & \multicolumn{2}{|c|}{ Sedimentation rate } \\
\hline & $\mathrm{AD}$ & \pm & $\mathrm{g} \mathrm{cm}^{-2} \mathrm{y}^{-1}$ & $\mathrm{~cm} \mathrm{y}^{-1}$ \\
\hline 3.75 & 1920 & 2 & 0.0048 & 0.035 \\
\hline 3.90 & 1915 & 3 & 0.0050 & 0.037 \\
\hline 4.05 & 1911 & 3 & 0.0053 & 0.038 \\
\hline 4.20 & 1907 & 3 & 0.0056 & 0.039 \\
\hline 4.35 & 1903 & 3 & 0.0058 & 0.040 \\
\hline 4.50 & 1900 & 4 & 0.0059 & 0.041 \\
\hline 4.65 & 1896 & 4 & 0.0061 & 0.042 \\
\hline 4.80 & 1892 & 4 & 0.0062 & 0.043 \\
\hline 4.95 & 1889 & 4 & 0.0067 & 0.046 \\
\hline 5.10 & 1886 & 4 & 0.0074 & 0.051 \\
\hline 5.25 & 1883 & 5 & 0.0082 & 0.056 \\
\hline 5.40 & 1880 & 5 & 0.0083 & 0.056 \\
\hline 5.55 & 1877 & 5 & 0.0077 & 0.052 \\
\hline 5.70 & 1874 & 5 & 0.0072 & 0.048 \\
\hline 5.85 & 1871 & 5 & 0.0071 & 0.047 \\
\hline 6.00 & 1868 & 6 & 0.0076 & 0.052 \\
\hline 6.30 & 1863 & 6 & 0.0086 & 0.060 \\
\hline 6.60 & 1858 & 7 & 0.0096 & 0.067 \\
\hline 6.90 & 1852 & 8 & 0.0085 & 0.060 \\
\hline 7.20 & 1845 & 9 & 0.0054 & 0.039 \\
\hline 7.50 & 1837 & 11 & 0.0038 & 0.028 \\
\hline 7.80 & 1826 & 15 & 0.0038 & 0.027 \\
\hline 8.10 & 1815 & 16 & 0.0038 & 0.027 \\
\hline 8.40 & 1804 & 17 & 0.0038 & 0.027 \\
\hline 8.70 & 1793 & 18 & 0.0038 & 0.027 \\
\hline 9.00 & 1781 & 19 & 0.0038 & 0.027 \\
\hline
\end{tabular}

The ${ }^{137}$ Cs activity versus depth profile (Fig. 3iii(b)) has a well defined but relatively poorly resolved peak. The maximum activity occurs at $1 \mathrm{~cm}$ depth, though the peak is skewed and high concentrations are recorded between 0.8-2.5 cm. Traces of ${ }^{241} \mathrm{Am}$ between 0.9-2.8 $\mathrm{cm}$ confirm the presence of weapons fallout between these depths, but do not allow precise identification of the 1963 depth. There were some indications of the presence of Chernobyl fallout in an earlier 1993 core from Redó and it is likely that the ${ }^{137} \mathrm{Cs}$ peak at $1 \mathrm{~cm}$ records the 1986 Chernobyl accident. The record between $1-2.5 \mathrm{~cm}$ will represent weapons fallout partially obscured by downward migrating Chernobyl ${ }^{137} \mathrm{Cs}$.

${ }^{210} \mathrm{~Pb}$ dates calculated using the CRS dating model place 1986 and 1963 at depths of $1 \mathrm{~cm}$ and $2.2 \mathrm{~cm}$ respectively, in good agreement with the conjecture of a Chernobyl origin for the ${ }^{137} \mathrm{Cs}$ peak at $1 \mathrm{~cm}$ and a 1960s origin for sediments just above $2.5 \mathrm{~cm}$. The chronology is similar to that for the 1993 core in that there were relatively low sedimentation rates up to $c a 1950$ and elevated sedimentation rates since then. Using the CRS model, the detailed results (Tab. 5) show that prior to 1950 sedimentation rates were low, varying between $0.004-0.008 \mathrm{~g} \mathrm{~cm}^{-2} \mathrm{y}^{-1}$. An episode of more rapid sedimentation in the latter half of the $19^{\text {th }}$ century not recorded in the 1993 core may be due to a local short-term slump or inwash event. Excluding the inwash event the two Redó cores have an almost identical mean pre-1950 sedimentation rate of $0.0046 \mathrm{~g} \mathrm{~cm}^{-2} \mathrm{y}^{-1}$. The basal value of $0.0038 \mathrm{~g} \mathrm{~cm}^{-2} \mathrm{y}^{-1}$ has been used to extrapolate the chronology below the ${ }^{210} \mathrm{~Pb}$ dating horizon back to

1781. Because of the inwash event the extrapolated dates do however have a higher degree of uncertainty.

\subsection{Sites with irregular changes in sedimentation}

\subsubsection{Nižné Terianske Pleso}

The unsupported ${ }^{210} \mathrm{~Pb}$ activity versus depth profile (Fig. 4i(a)) has a major irregularity below $c a 1.5 \mathrm{~cm}$ that appears to be associated with a layer of dense sediment between 1.4-4.0 cm. There are a number of other dense layers at various depths throughout the core, in particular between $6-8 \mathrm{~cm}$, just beneath the ${ }^{210} \mathrm{~Pb}$ equilibrium depth. Similar features were observed in an earlier 1993 core from this lake.

Very high ${ }^{137} \mathrm{Cs}$ concentrations in the surficial sediments indicate that the ${ }^{137} \mathrm{Cs}$ record in this core is dominated by fallout from the 1986 Chernobyl accident. Significant levels of ${ }^{241} \mathrm{Am}$ activity detected between 0.2 $1.0 \mathrm{~cm}$ (Fig. 4i(b)) suggest that sediments between these two depths record the period of maximum fallout from the atmospheric testing of nuclear weapons in the 1960s. Because of the close proximity to the surficial sediments the weapons ${ }^{137} \mathrm{Cs}$ record will almost certainly have been obscured by downward migration of Chernobyl ${ }^{137} \mathrm{Cs}$.

Neither of the simple ${ }^{210} \mathrm{~Pb}$ dating models date this core satisfactorily. The CRS model suggests that the non-monotonic section of the ${ }^{210} \mathrm{~Pb}$ profile between 1.5$4 \mathrm{~cm}$ was associated with an episode of rapid sedimentation in the early part of the $20^{\text {th }}$ century, but places 1963 at a depth of $1.2 \mathrm{~cm}$, a little below that indicated 
i(a)

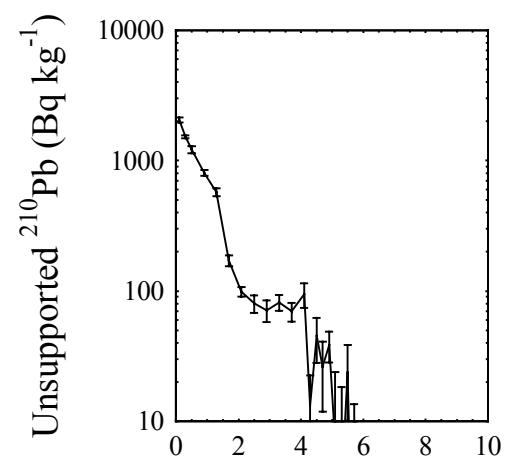

i(b)

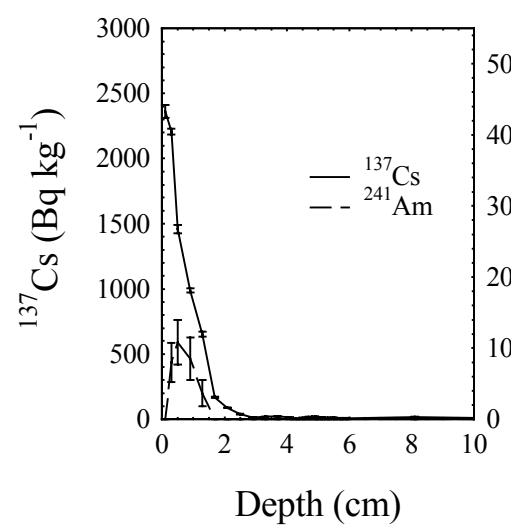

ii(a)

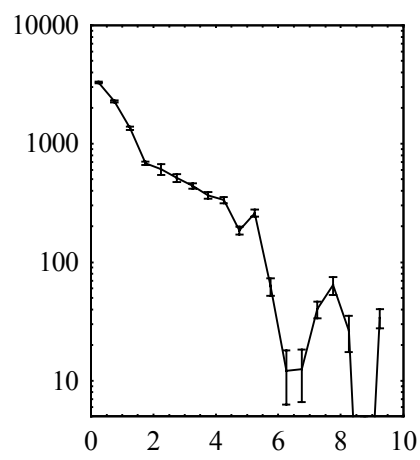

ii(b) iii(b)

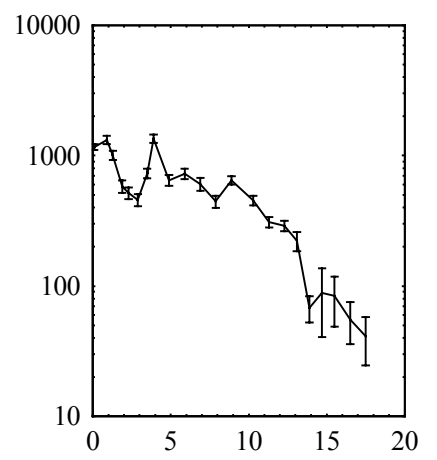

iii(b)

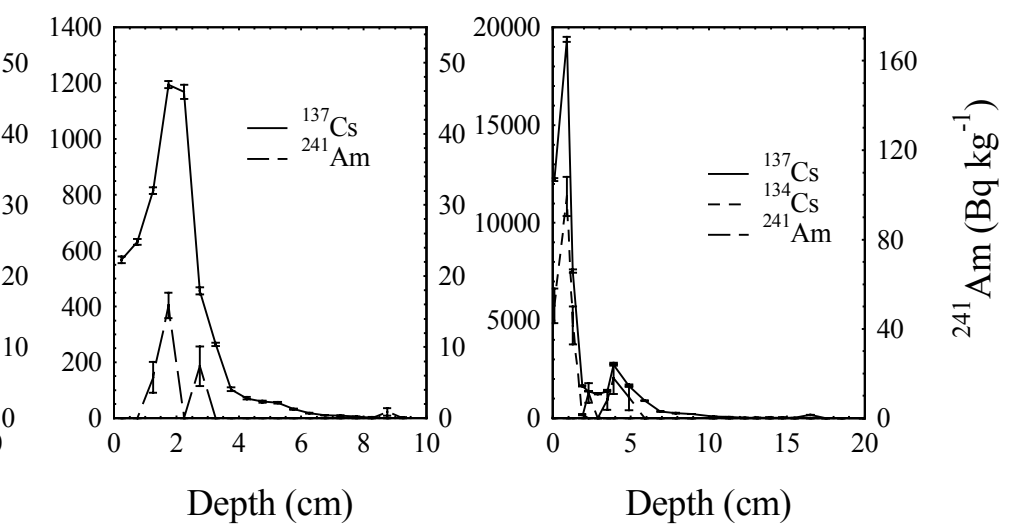

Fig. 4. Fallout radionuclides in (i) Nižné Terianske, (ii) Hagelsee, (iii) Ledvicah showing (a) unsupported ${ }^{210} \mathrm{~Pb}$ and $(\mathbf{b}){ }^{137} \mathrm{Cs}$ activities versus depth in the core. In each of these cores there is evidence of irregular episodes of accelerated sedimentation.

Tab. 6. ${ }^{210} \mathrm{~Pb}$ chronology of Nižné Terianske core TERI96/7 (in italics extrapolated dates).

\begin{tabular}{lcccc}
\hline $\begin{array}{l}\text { Depth } \\
\mathrm{cm}\end{array}$ & \multicolumn{2}{c}{ Date } & \multicolumn{2}{c}{ Sedimentation rate } \\
$\mathrm{g} \mathrm{cm}^{-2} \mathrm{y}^{-1}$ & $\mathrm{~cm} \mathrm{y}^{-1}$ \\
\hline 0.0 & 1996 & & & \\
0.2 & 1992 & 2 & 0.0038 & 0.044 \\
0.4 & 1987 & 2 & 0.0042 & 0.037 \\
0.6 & 1981 & 2 & 0.0044 & 0.032 \\
0.8 & 1974 & 2 & 0.0044 & 0.028 \\
1.0 & 1967 & 2 & 0.0042 & 0.025 \\
1.2 & 1959 & 2 & 0.0038 & 0.022 \\
1.4 & 1949 & 2 & 0.0067 & 0.025 \\
1.6 & 1943 & 2 & 0.0101 & 0.033 \\
1.8 & 1937 & 2 & 0.0132 & 0.039 \\
2.0 & 1932 & 2 & 0.0150 & 0.043 \\
2.2 & 1928 & 3 & 0.0157 & 0.045 \\
2.4 & 1923 & 3 & 0.0152 & 0.049 \\
2.6 & 1920 & 4 & 0.0147 & 0.058 \\
2.8 & 1916 & 4 & 0.0141 & 0.060 \\
3.0 & 1913 & 5 & 0.0126 & 0.053 \\
\hline
\end{tabular}

\begin{tabular}{lcccc}
\hline $\begin{array}{l}\text { Depth } \\
\mathrm{cm}\end{array}$ & \multicolumn{2}{c}{ Date } & \multicolumn{2}{c}{ Sedimentation rate } \\
$\mathrm{g} \mathrm{cm}^{-2} \mathrm{y}^{-1}$ & $\mathrm{~cm} \mathrm{y}^{-1}$ \\
\hline 3.2 & 1909 & 5 & 0.0104 & 0.046 \\
3.4 & 1904 & 6 & 0.0090 & 0.040 \\
3.6 & 1899 & 7 & 0.0083 & 0.032 \\
3.8 & 1892 & 9 & 0.0064 & 0.027 \\
4.0 & 1884 & 10 & 0.0034 & 0.022 \\
4.2 & 1872 & 10 & 0.0034 & 0.020 \\
4.4 & 1862 & 11 & 0.0034 & 0.020 \\
4.6 & 1852 & 12 & 0.0034 & 0.020 \\
4.8 & 1842 & 13 & 0.0034 & 0.021 \\
4.9 & 1838 & 13 & 0.0034 & 0.021 \\
5.0 & 1833 & 14 & 0.0034 & 0.021 \\
5.2 & 1823 & 15 & 0.0034 & 0.021 \\
5.4 & 1814 & 15 & 0.0034 & 0.021 \\
5.6 & 1803 & 16 & 0.0034 & 0.020 \\
5.8 & 1794 & 17 & 0.0034 & 0.019 \\
6.0 & 1784 & 18 & 0.0034 & 0.017 \\
\hline
\end{tabular}

by the ${ }^{241} \mathrm{Am}$ results. The CIC model is in better agreement with the ${ }^{137} \mathrm{Cs} /{ }^{241} \mathrm{Am}$ record, placing 1986 at 0.3 $\mathrm{cm}$ and 1963 at $0.9 \mathrm{~cm}$, but cannot date the non-monotonic section in which initial concentrations were clearly diluted. Looking at the results as a whole it appears that the record in this lake is one of low but uniform sedimentation throughout most of its history, punctuated from time to time by episodes of rapid accumulation of dense sediment, possibly due to intermittent slumps from the catchment or from the margins of the lake. Importation of additional ${ }^{210} \mathrm{~Pb}$ to the core site with the slump has resulted in just a partial dilution of the initial ${ }^{210} \mathrm{~Pb}$ concentration, causing errors in the CRS model when applied to the core as a whole. Such cores can 
however be dated using a piecewise CRS model (Appleby 1998) in which the ${ }^{210} \mathrm{~Pb}$ supply is assumed to be uniform only within each distinct zone in the core. Assuming uniform sedimentation rates in the upper zone $(<1.4 \mathrm{~cm})$, the lower boundary of this zone at $1.4 \mathrm{~cm}$ is dated 1949. The mean post-1949 sedimentation rate is calculated to be $0.0041 \pm 0.0014 \mathrm{~g} \mathrm{~cm}^{-2} \mathrm{y}^{-1}$, and the mean ${ }^{210} \mathrm{~Pb}$ flux during this period $77 \mathrm{~Bq} \mathrm{~m} \mathrm{~m}^{-2} \mathrm{y}^{-1}$. Assuming that these normal conditions also apply to sediments in the deeper zone below $4 \mathrm{~cm}$, the upper boundary of the deeper zone at $4 \mathrm{~cm}$ is dated 1884 . The intermediate zone $(1.4-4.0 \mathrm{~cm})$ thus spans the period $1884-1949$. The mean sedimentation rate during this time is $0.010 \mathrm{~g} \mathrm{~cm}^{-2}$ $\mathrm{y}^{-1}$, and the mean ${ }^{210} \mathrm{~Pb}$ flux $123 \mathrm{~Bq} \mathrm{~m}^{-2} \mathrm{y}^{-1}$. Although the detailed results (Tab. 6) suggest elevated accumulation rates throughout the whole of this period, these are most likely an artefact of the calculations caused by the intrusion of a major disturbance on a slow depositional sequence. The episode of rapid sedimentation is likely to have been a relatively brief event in the late 1920 s. The 1993 core records a similar event at about the same time. Since there may have been some mixing with adjoining layers, dates of sediments between $1.4-4 \mathrm{~cm}$ are problematic. Dates above $1.4 \mathrm{~cm}$ and below $4 \mathrm{~cm}$ that weren't influenced by this event are likely to be more secure. The mean sedimentation rate in sediments below $4 \mathrm{~cm}$ is estimated to be $0.0034 \mathrm{~g} \mathrm{~cm}^{-2}$, and this value has been used to extrapolate the chronology back to the late $18^{\text {th }}$ century.

\subsubsection{Hagelsee}

The unsupported ${ }^{210} \mathrm{~Pb}$ activity versus depth profile in this core (Fig. 4ii(a)) can be divided into three distinct zones.

- In the uppermost zone $(0-2 \mathrm{~cm})$ activity declines steeply with depth, from a very high value (3290 \pm $58 \mathrm{~Bq} \mathrm{~kg}^{-1}$ ) in the surficial sample to $684 \pm 23 \mathrm{~Bq}$ $\mathrm{kg}^{-1}$ at $1.5-2.0 \mathrm{~cm}$.

- In the middle zone $(2-4.5 \mathrm{~cm}){ }^{210} \mathrm{~Pb}$ activity continues to decline more or less exponentially with depth though at a distinctly shallower gradient.

- In the deeper zone $(4.5-9.5 \mathrm{~cm})$ the profile becomes more irregular, with significant non-monotonic features at 6-7 $\mathrm{cm}$ and $8.5-9 \mathrm{~cm}$. Both coincide with layers of relatively dense inorganic sediment and may record brief episodes of rapid sedimentation due e.g. to slump events.

${ }^{210} \mathrm{~Pb}$ equilibrium occurs at a depth of about $10 \mathrm{~cm}$.

The ${ }^{137} \mathrm{Cs}$ profile (Fig. 4ii(b)) has a fairly well resolved peak between $1.5-2.5 \mathrm{~cm}$ depth. Traces of ${ }^{241} \mathrm{Am}$ suggest that this feature records the 1963 fallout maximum from the atmospheric testing of nuclear weapons (Appleby et al. 1991). Although fallout from the 1986 Chernobyl accident was widespread in Switzerland, results from Brienzersee ( $c a 4 \mathrm{~km}$ from Hagelsee) indicate relatively little Chernobyl deposition in this locality (Lotter, pers. comm.).
Dates calculated by ${ }^{210} \mathrm{~Pb}$ place 1963 at between 1.1 $\mathrm{cm}$ (CIC model) and $2.75 \mathrm{~cm}$ (CRS model), supporting the inference that the ${ }^{137} \mathrm{Cs}$ peak at $2.0 \pm 0.5 \mathrm{~cm}$ is of weapons origin. The discrepancies between the two sets of ${ }^{210} \mathrm{~Pb}$ dates and the ${ }^{137} \mathrm{Cs}$ record suggest that the recent reduction in sedimentation rates implied by both models is associated with a small decline in the ${ }^{210} \mathrm{~Pb}$ flux. Since the changes are broadly in proportion, the most likely cause is a shift in the pattern of sediment focussing.

Although corrected CRS model dates can be calculated using the $1963{ }^{137} \mathrm{Cs}$ date as a reference point, errors can still arise due to variations in the ${ }^{210} \mathrm{~Pb}$ supply rate at individual core sites due to local irregularities in the process of sedimentation. Where two or more cores have been assayed for radionuclides, uncertainties can be reduced by correlating the cores and treating them as a single record. Samples from a second MOLAR core (HAG96-3) were analysed at EAWAG (Switzerland) for ${ }^{137} \mathrm{Cs}$ and ${ }^{210} \mathrm{~Pb}$ (Lotter et al. 2000). Combining the data from both cores, a chronology for the master core (HAG96-1) was calculated using the correlated CRS ${ }^{210} \mathrm{~Pb}$ dating model (Oldfield et al. 1980), and the 1963 ${ }^{137} \mathrm{Cs}$ date as a reference point. The results, given in table 7 , indicate a relatively uniform sedimentation rate throughout most of the past 150 years, fluctuating about a mean value of $0.011 \pm 0.002 \mathrm{~g} \mathrm{~cm}^{-2} \mathrm{y}^{-1}$ apart from a single brief episode of very rapid accumulation between 6 and $7 \mathrm{~cm}$ (dated 1883-1894). This event is recorded as a layer of dense sediment in all 5 Hagelsee cores, and by dilution features in both ${ }^{210} \mathrm{~Pb}$ profiles (at $6-7 \mathrm{~cm}$ in HAG96-1 and 7-8 cm in HAG96-3). Sedimentation rates appear to have decline during the past few decades. The mean post-1963 sedimentation rate in HAG96-1 is $0.0061 \pm 0.0010 \mathrm{~g} \mathrm{~cm}^{-2} \mathrm{y}^{-1}$.

Because of the large uncertainties in calculated dates near the ${ }^{210} \mathrm{~Pb}$ dating horizon, dates prior to 1883 have been recalculated using the mean 1894-1963 accumulation rate of $0.011 \pm 0.002 \mathrm{~g} \mathrm{~cm}^{-2} \mathrm{y}^{-1}$. This value has also been used to extrapolate the chronology below the dating horizon back to the late $18^{\text {th }}$ century.

\subsubsection{Jezero Ledvicah}

The record of unsupported ${ }^{210} \mathrm{~Pb}$ activity in this core has several non-monotonic features, the most severe of which occurs between 1.8-3.6 cm (Fig. 4iii(a)). Although accumulation rates appear to have been much more rapid than at other sites, ${ }^{210} \mathrm{~Pb}$ equilibrium not being reached until a depth of about $20 \mathrm{~cm}$, this is mainly due to the very low sediment density. Expressed in terms of cumulative dry mass the depth of the ${ }^{210} \mathrm{~Pb}$ dating horizon is comparable to that at other sites.

The ${ }^{137}$ Cs activity versus depth profile (Fig. 4iii(b)) is dominated by a well resolved peak at $0.9 \mathrm{~cm}$. In view of the very high ${ }^{137} \mathrm{Cs}$ activity in the peak $(19380 \pm 127$ $\mathrm{Bq} \mathrm{kg}^{-1}$ ), the most likely origin is fallout from the 1986 Chernobyl accident. This is confirmed by the detection 
Tab. 7. ${ }^{210} \mathrm{~Pb}$ chronology of Hagelsee core HAG96/1 (in italics extrapolated dates).

\begin{tabular}{lcccc}
\hline \multirow{2}{*}{$\begin{array}{l}\text { Depth } \\
\mathrm{cm}\end{array}$} & \multicolumn{2}{c}{ Date } & \multicolumn{2}{c}{ Sedimentation rate } \\
& $\mathrm{AD}$ & \pm & $\mathrm{g} \mathrm{cm}^{-2} \mathrm{y}^{-1}$ & $\mathrm{~cm} \mathrm{y}^{-1}$ \\
\hline 0.00 & 1996 & & & \\
0.25 & 1992 & 2 & 0.0043 & 0.064 \\
0.50 & 1989 & 2 & 0.0046 & 0.061 \\
0.75 & 1985 & 2 & 0.0049 & 0.058 \\
1.00 & 1981 & 3 & 0.0056 & 0.057 \\
1.25 & 1976 & 3 & 0.0062 & 0.055 \\
1.50 & 1972 & 4 & 0.0078 & 0.061 \\
1.75 & 1967 & 4 & 0.0093 & 0.066 \\
2.00 & 1964 & 4 & 0.0114 & 0.077 \\
2.25 & 1961 & 5 & 0.0135 & 0.087 \\
2.50 & 1958 & 5 & 0.0134 & 0.083 \\
2.75 & 1955 & 5 & 0.0133 & 0.078 \\
3.00 & 1951 & 5 & 0.0129 & 0.073 \\
3.25 & 1948 & 5 & 0.0125 & 0.068 \\
3.50 & 1944 & 5 & 0.0122 & 0.065 \\
3.75 & 1940 & 5 & 0.0119 & 0.061 \\
4.00 & 1935 & 5 & 0.0108 & 0.053 \\
4.25 & 1931 & 5 & 0.0097 & 0.044 \\
4.50 & 1925 & 5 & 0.0111 & 0.050 \\
4.75 & 1920 & 5 & 0.0125 & 0.056 \\
5.00 & 1914 & 5 & 0.0093 & 0.042 \\
5.25 & 1908 & 5 & 0.0061 & 0.027 \\
5.50 & 1902 & 5 & 0.0117 & 0.042 \\
\hline & & & &
\end{tabular}

\begin{tabular}{|c|c|c|c|c|}
\hline \multirow{2}{*}{$\begin{array}{l}\text { Depth } \\
\mathrm{cm}\end{array}$} & \multicolumn{2}{|c|}{ Date } & \multicolumn{2}{|c|}{ Sedimentation rate } \\
\hline & $\mathrm{AD}$ & \pm & $\mathrm{g} \mathrm{cm}^{-2} \mathrm{y}^{-1}$ & $\mathrm{~cm} \mathrm{y}^{-1}$ \\
\hline 5.75 & 1896 & 6 & 0.0173 & 0.057 \\
\hline 6.00 & 1893 & 6 & 0.046 & 0.110 \\
\hline 6.25 & 1890 & 6 & 0.075 & 0.162 \\
\hline 6.50 & 1888 & 6 & 0.069 & 0.143 \\
\hline 6.75 & 1886 & 6 & 0.064 & 0.124 \\
\hline 7.00 & 1882 & 6 & 0.040 & 0.084 \\
\hline 7.25 & 1878 & 6 & 0.015 & 0.044 \\
\hline 7.50 & 1870 & 7 & 0.011 & 0.042 \\
\hline 7.75 & 1863 & 8 & 0.011 & 0.040 \\
\hline 8.00 & 1858 & 9 & 0.011 & 0.042 \\
\hline 8.25 & 1853 & 10 & 0.011 & 0.044 \\
\hline 8.50 & 1846 & 11 & 0.011 & 0.041 \\
\hline 8.75 & 1840 & 12 & 0.011 & 0.039 \\
\hline 9.00 & 1834 & 14 & 0.011 & 0.039 \\
\hline 9.25 & 1827 & 17 & 0.011 & 0.039 \\
\hline 9.50 & 1821 & & 0.011 & 0.039 \\
\hline 9.75 & 1815 & & 0.011 & 0.039 \\
\hline 10.00 & 1808 & & 0.011 & 0.039 \\
\hline 10.25 & 1801 & & 0.011 & 0.039 \\
\hline 10.50 & 1795 & & 0.011 & 0.039 \\
\hline 10.75 & 1790 & & 0.011 & 0.039 \\
\hline 11.00 & 1783 & & 0.011 & 0.039 \\
\hline
\end{tabular}

of a similar peak in ${ }^{134} \mathrm{Cs}$ concentrations at the same depth. The ${ }^{134} \mathrm{Cs} /{ }^{137} \mathrm{Cs}$ ratio in the peak is typical of Chernobyl fallout. A smaller but still well resolved ${ }^{137} \mathrm{Cs}$ peak was detected further down the core at $3.9 \mathrm{~cm}$ depth. The presence of a significant peak in ${ }^{241} \mathrm{Am}$ activity at the same depth confirms that this feature records the 1963 weapons fallout maximum.

${ }^{210} \mathrm{~Pb}$ dates calculated using the CRS model place 1986 at a depth of $2.6 \mathrm{~cm}$ and 1963 at a depth of $7.7 \mathrm{~cm}$. The CIC model could not be used because of the nonmonotonic variations in ${ }^{210} \mathrm{~Pb}$ activity near the top of the core. The large discrepancies between the ${ }^{210} \mathrm{~Pb}$ and ${ }^{137} \mathrm{Cs}$ dates show that in recent decades there have been significant changes in the ${ }^{210} \mathrm{~Pb}$ supply rate. Applying the CRS model in a piecewise manner using the 1986 and $1963{ }^{137} \mathrm{Cs}$ dates as reference points, three brief episodes of rapid sedimentation can be identified, in the late $19^{\text {th }}$ century, between 1944-56, and in the mid1970s. These are thought to be due to sediment slumps caused by earthquakes in this region in 1895, 1942 and 1975/6 (Brancelj et al. 2000). Normal sedimentation rates excluding these events are in the range 0.0052$0.0071 \mathrm{~g} \mathrm{~cm}^{-2} \mathrm{y}^{-1}$. The results are given in detail in table 8. Extrapolated sediment dates below the ${ }^{210} \mathrm{~Pb}$ dating horizon have been calculated using the estimated basal sedimentation rate of $0.005 \mathrm{~g} \mathrm{~cm}^{-2} \mathrm{y}^{-1}$.

\section{DISCUSSION}

Table 9 summarises a number of radiometric parameters from each site. The high unsupported ${ }^{210} \mathrm{~Pb}$ concentrations in the surficial sediments (ranging from $508-3116 \mathrm{~Bq} \mathrm{~kg}^{-1}$ ) are indicative of the low sedimentation rates typical of these lakes. Mean accumulation rates since $\mathrm{ca} 1850$ range from $0.0032 \mathrm{~g} \mathrm{~cm}^{-2} \mathrm{y}^{-1}$ in Gossenköllesee to $0.015 \mathrm{~g} \mathrm{~cm}^{-2} \mathrm{y}^{-1}$ in Saanajärvi. Although the high concentrations are advantageous in the sense that they push the ${ }^{210} \mathrm{~Pb}$ dating horizon back to the mid $19^{\text {th }}$ century ( $c a 7^{210} \mathrm{~Pb}$ half-lives), the low sedimentation rates do make the sediment record vulnerable to disturbance by quite small events. These are observed in a number of cores as irregularities in the ${ }^{210} \mathrm{~Pb}$ record and/or abrupt changes in the dry bulk density. The most reliable results are those from sites where there has been long-term stability in the supply of both sediment and fallout ${ }^{210} \mathrm{~Pb}$. At such sites it is possible to extrapolate dates below the ${ }^{210} \mathrm{~Pb}$ dating horizon back to 1781 with a high degree of confidence.

\section{1. ${ }^{210} \mathrm{~Pb}$ supply rates}

Direct measurements of fallout carried out within the MOLAR program indicate that the atmospheric flux of ${ }^{210} \mathrm{~Pb}$ is between $66-91 \mathrm{~Bq} \mathrm{~m}^{-2} \mathrm{y}^{-1}$ per meter of rainfall at those sites close to the Atlantic or Arctic (Øvre Neådalsvatn, Saanajärvi, Redó), and between 130-173 $\mathrm{Bq} \mathrm{m} \mathrm{y}^{-1}$ per meter of rainfall at sites in Central Europe (Hagelsee, Gossenköllesee, Ledvicah, Nižné Terianske Pleso). Cores sites where the mean ${ }^{210} \mathrm{~Pb}$ supply rate (Tab. 9) is well in excess of the estimated atmospheric flux include Saanajärvi and Redó. Cores sites that appear to have a significant deficiency include Terianske, Gossenköllesee and Ledvicah. High ${ }^{210} \mathrm{~Pb}$ supply rates can be due to sediment focussing, or significant inputs from the catchment. Low values can be due to remobilisation of sediment away from the core site. Differences between the atmospheric flux (which can be assumed constant) and the ${ }^{210} \mathrm{~Pb}$ supply rate will not necessarily 
Tab. 8. ${ }^{210} \mathrm{~Pb}$ chronology of Jezero v Ledvicah core LEDV5.

\begin{tabular}{|c|c|c|c|c|}
\hline \multirow{2}{*}{$\begin{array}{l}\text { Depth } \\
\mathrm{cm}\end{array}$} & \multicolumn{2}{|c|}{ Date } & \multicolumn{2}{|c|}{ Sedimentation rate } \\
\hline & $\mathrm{AD}$ & \pm & $\mathrm{g} \mathrm{cm}^{-2} \mathrm{y}^{-1}$ & $\mathrm{~cm} \mathrm{y}^{-1}$ \\
\hline 0.00 & 1996 & & & \\
\hline 0.20 & 1994 & 1 & 0.0058 & 0.096 \\
\hline 0.40 & 1992 & 1 & 0.0056 & 0.096 \\
\hline 0.60 & 1990 & 1 & 0.0050 & 0.095 \\
\hline 0.80 & 1988 & 2 & 0.0047 & 0.099 \\
\hline 1.00 & 1986 & 2 & 0.0046 & 0.104 \\
\hline 1.20 & 1984 & 2 & 0.0057 & 0.113 \\
\hline 1.40 & 1982 & 2 & 0.0070 & 0.124 \\
\hline 1.60 & 1981 & 2 & 0.0087 & 0.129 \\
\hline 1.80 & 1979 & 2 & 0.0098 & 0.138 \\
\hline 2.00 & 1978 & 2 & 0.0105 & 0.151 \\
\hline 2.20 & 1976 & 2 & 0.0109 & 0.159 \\
\hline 2.40 & 1975 & 2 & 0.0110 & 0.164 \\
\hline 2.60 & 1974 & 2 & 0.0111 & 0.162 \\
\hline 2.80 & 1973 & 2 & 0.0107 & 0.151 \\
\hline 3.00 & 1972 & 2 & 0.0098 & 0.132 \\
\hline 3.20 & 1970 & 2 & 0.0082 & 0.120 \\
\hline 3.40 & 1968 & 2 & 0.0065 & 0.118 \\
\hline 3.60 & 1966 & 2 & 0.0050 & 0.116 \\
\hline 3.80 & 1965 & 2 & 0.0038 & 0.119 \\
\hline 4.00 & 1963 & 2 & 0.0033 & 0.122 \\
\hline 4.20 & 1961 & 2 & 0.0034 & 0.122 \\
\hline 4.40 & 1960 & 3 & 0.0037 & 0.140 \\
\hline 4.60 & 1958 & 3 & 0.0041 & 0.167 \\
\hline 4.80 & 1957 & 4 & 0.010 & 0.193 \\
\hline 5.00 & 1957 & 4 & 0.016 & 0.226 \\
\hline 5.20 & 1956 & 4 & 0.019 & 0.224 \\
\hline 5.40 & 1955 & 4 & 0.020 & 0.225 \\
\hline 5.60 & 1954 & 4 & 0.020 & 0.239 \\
\hline 5.80 & 1953 & 4 & 0.020 & 0.252 \\
\hline 6.00 & 1952 & 4 & 0.020 & 0.265 \\
\hline 6.20 & 1951 & 5 & 0.020 & 0.280 \\
\hline 6.40 & 1951 & 5 & 0.020 & 0.287 \\
\hline 6.60 & 1950 & 5 & 0.020 & 0.297 \\
\hline 6.80 & 1949 & 5 & 0.020 & 0.315 \\
\hline 7.00 & 1949 & 5 & 0.020 & 0.337 \\
\hline 7.20 & 1948 & 5 & 0.020 & 0.362 \\
\hline 7.40 & 1948 & 5 & 0.020 & 0.374 \\
\hline 7.60 & 1947 & 5 & 0.020 & 0.369 \\
\hline 7.80 & 1947 & 5 & 0.020 & 0.356 \\
\hline 8.00 & 1946 & 5 & 0.020 & 0.339 \\
\hline 8.20 & 1945 & 4 & 0.019 & 0.320 \\
\hline 8.40 & 1945 & 4 & 0.018 & 0.294 \\
\hline 8.60 & 1944 & 4 & 0.017 & 0.252 \\
\hline 8.80 & 1943 & 4 & 0.013 & 0.198 \\
\hline 9.00 & 1942 & 4 & 0.010 & 0.155 \\
\hline 9.20 & 1941 & 4 & 0.0071 & 0.129 \\
\hline 9.40 & 1939 & 4 & 0.0070 & 0.115 \\
\hline
\end{tabular}

\begin{tabular}{|c|c|c|c|c|}
\hline \multirow{2}{*}{$\begin{array}{l}\text { Depth } \\
\mathrm{cm}\end{array}$} & \multicolumn{2}{|c|}{ Date } & \multicolumn{2}{|c|}{ Sedimentation rate } \\
\hline & $\mathrm{AD}$ & \pm & $\mathrm{g} \mathrm{cm}^{-2} \mathrm{y}^{-1}$ & $\mathrm{~cm} \mathrm{y}^{-1}$ \\
\hline 9.60 & 1937 & 4 & 0.0070 & 0.109 \\
\hline 9.80 & 1935 & 4 & 0.0070 & 0.108 \\
\hline 10.00 & 1933 & 4 & 0.0069 & 0.108 \\
\hline 10.20 & 1932 & 4 & 0.0069 & 0.107 \\
\hline 10.40 & 1930 & 4 & 0.0069 & 0.107 \\
\hline 10.60 & 1928 & 4 & 0.0070 & 0.108 \\
\hline 10.80 & 1926 & 4 & 0.0072 & 0.110 \\
\hline 11.00 & 1924 & 4 & 0.0073 & 0.108 \\
\hline 11.20 & 1922 & 4 & 0.0074 & 0.102 \\
\hline 11.40 & 1920 & 4 & 0.0072 & 0.095 \\
\hline 11.60 & 1918 & 4 & 0.0069 & 0.087 \\
\hline 11.80 & 1916 & 4 & 0.0064 & 0.080 \\
\hline 12.00 & 1913 & 5 & 0.0060 & 0.076 \\
\hline 12.20 & 1910 & 5 & 0.0057 & 0.071 \\
\hline 12.40 & 1908 & 5 & 0.0054 & 0.068 \\
\hline 12.60 & 1905 & 6 & 0.0052 & 0.066 \\
\hline 12.80 & 1901 & 6 & 0.0051 & 0.066 \\
\hline 13.00 & 1898 & 7 & 0.0051 & 0.070 \\
\hline 13.20 & 1895 & 7 & 0.0057 & 0.079 \\
\hline 13.40 & 1893 & 8 & 0.0070 & 0.094 \\
\hline 13.60 & 1891 & 8 & 0.0089 & 0.113 \\
\hline 13.80 & 1890 & 9 & 0.0105 & 0.129 \\
\hline 14.00 & 1888 & 9 & 0.0110 & 0.135 \\
\hline 14.20 & 1887 & 9 & 0.0105 & 0.130 \\
\hline 14.40 & 1885 & 10 & 0.0093 & 0.110 \\
\hline 14.60 & 1884 & 10 & 0.0083 & 0.087 \\
\hline 14.80 & 1881 & 10 & 0.0075 & 0.071 \\
\hline 15.00 & 1878 & 11 & 0.0067 & 0.059 \\
\hline 15.20 & 1874 & 12 & 0.0061 & 0.054 \\
\hline 15.40 & 1870 & 13 & 0.0056 & 0.054 \\
\hline 15.60 & 1866 & 14 & 0.0052 & 0.055 \\
\hline 15.80 & 1863 & 16 & 0.0050 & 0.057 \\
\hline 16.00 & 1859 & 17 & 0.0050 & 0.059 \\
\hline 16.20 & 1856 & 19 & 0.0050 & 0.058 \\
\hline 16.40 & 1853 & 21 & 0.0050 & 0.058 \\
\hline 16.60 & 1849 & 22 & 0.0050 & 0.057 \\
\hline 16.80 & 1846 & 23 & 0.0050 & 0.056 \\
\hline 17.00 & 1842 & 24 & 0.0050 & 0.056 \\
\hline 17.20 & 1838 & 24 & 0.0050 & 0.052 \\
\hline 17.40 & 1835 & 25 & 0.0050 & 0.045 \\
\hline 17.60 & 1830 & & 0.0050 & 0.038 \\
\hline 17.80 & 1824 & & 0.0050 & 0.034 \\
\hline 18.00 & 1818 & & 0.0050 & 0.031 \\
\hline 18.20 & 1811 & & 0.0050 & 0.029 \\
\hline 18.40 & 1804 & & 0.0050 & 0.029 \\
\hline 18.60 & 1797 & & 0.0050 & 0.029 \\
\hline 18.80 & 1790 & & 0.0050 & 0.029 \\
\hline 19.00 & 1783 & & 0.0050 & 0.029 \\
\hline
\end{tabular}

invalidate the CRS model. Errors will only arise if the intensity of these processes changes over a significant period of time.

The results from Øvre Neådalsvatn, Saanajärvi, Redó and Gossenköllesee suggest that the processes controlling ${ }^{210} \mathrm{~Pb}$ supply rates at these sites have been relatively stable over a long period of time. In cores from Terianske, Ledvicah and Hagelsee there was however evidence of varying inputs of ${ }^{210} \mathrm{~Pb}$. At such sites, for sections of the core bounded by reference points of known ages $t_{1}$ and $t_{2}$, the mean ${ }^{210} \mathrm{~Pb}$ supply rate during the intervening period can be calculated using the formula:

$$
P=\frac{\lambda \Delta A}{\mathrm{e}^{-\lambda t_{1}}-\mathrm{e}^{-\lambda t_{2}}}
$$

where $\Delta \mathrm{A}$ is the ${ }^{210} \mathrm{~Pb}$ inventory between the reference points (Appleby 1998). At Hagelsee, changes in ${ }^{210} \mathrm{~Pb}$ supply rates appear to be due to variations in the pattern of sediment focussing. At Terianske the cause appears to be a sediment slump in the 1920s. At Ledvicah disproportionately higher fluxes in the pre-1963 sediments point to a significant catchment input during the earlier part of the record. In spite of these processes, reliable dates can be still be calculated at these sites 
Tab. 9. Radiometric inventories of the MOLAR cores. Also shown are the unsupported ${ }^{210} \mathrm{~Pb}$ concentrations in the surficial sediments, and the ${ }^{210} \mathrm{~Pb}$ fluxes required to sustain the measured ${ }^{210} \mathrm{~Pb}$ inventories. The ${ }^{137} \mathrm{Cs}$ inventories included estimates of the contributions from nuclear weapons tests and Chernobyl fallout.

\begin{tabular}{lcccccc}
\hline & \multicolumn{3}{c}{ Unsupported ${ }^{210} \mathrm{~Pb}$} & & \multicolumn{2}{c}{${ }^{137}$ Cs inventory } \\
\cline { 2 - 3 } & $\begin{array}{c}\text { Surface conc. } \\
\mathrm{Bq} \mathrm{kg}^{-1}\end{array}$ & $\begin{array}{c}\text { Inventory } \\
\mathrm{Bq} \mathrm{m}^{-2}\end{array}$ & $\begin{array}{c}\text { Flux } \\
\mathrm{Bq} \mathrm{m}^{-2} \mathrm{y}^{-1}\end{array}$ & & $\begin{array}{c}\text { Weapons } \\
\mathrm{Bq} \mathrm{m}^{-2}\end{array}$ & $\begin{array}{c}\text { Chernobyl } \\
\mathrm{Bq} \mathrm{m}^{-2}\end{array}$ \\
\hline Saanajärvi & 914 & 12137 & 378 & & 10773 & 1276 \\
Øvre Neådalsvatn & 888 & 3030 & 94 & & 3879 & 1487 \\
Nižné Terianske & 2049 & 2760 & 86 & & 2466 & 2627 \\
Gossenköllesee & 508 & 2135 & 66 & & 2971 & 640 \\
Hagelsee & 590 & 7337 & 228 & & 11130 & \\
Ledvicah & 1162 & 5260 & 164 & & 13790 & 22672 \\
Redó & 3116 & 10085 & 314 & & 17568 & \\
\hline
\end{tabular}

(a)

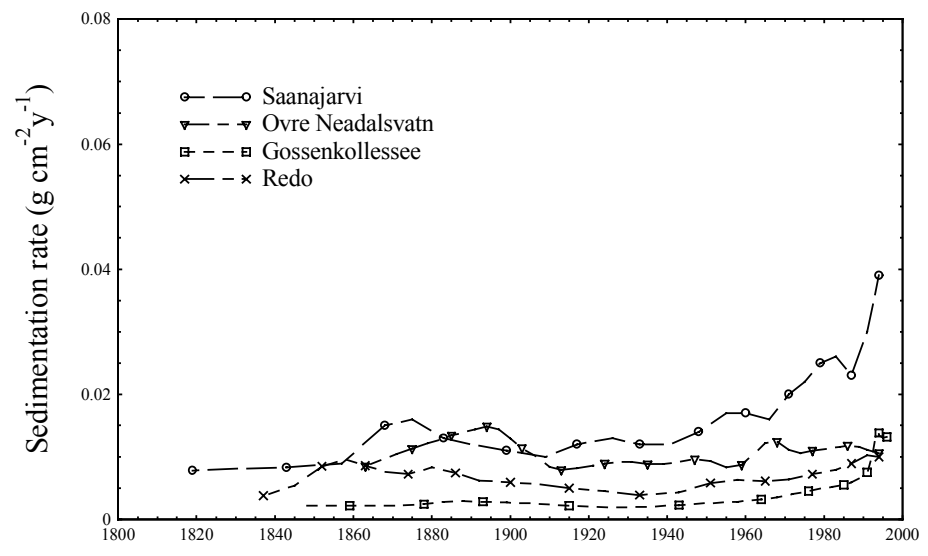

(b)

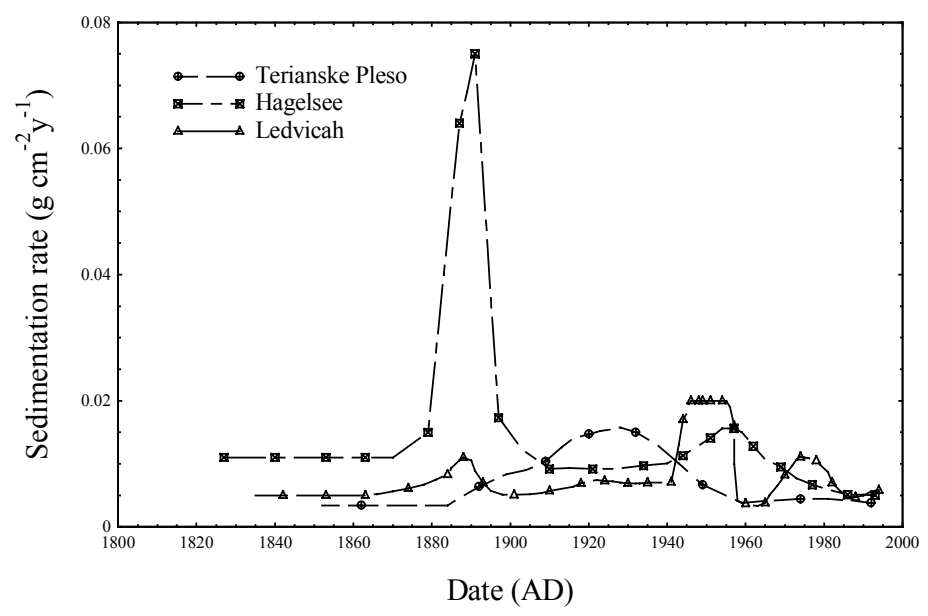

Fig. 5. Sedimentation rates versus time for (a) sites with relatively uniform accumulation pre-1963 and (b) sites with significant irregularities in the deeper sections of the core. using the composite CRS model, though the method does becomes increasingly uncertain when the ${ }^{210} \mathrm{~Pb}$ irregularities occur in the deeper sections of the core.

\subsection{Dry Bulk density changes}

Layers of dense sediment create two kinds of uncertainty, particularly in the deeper sections of a core.
Where they occur just above the ${ }^{210} \mathrm{~Pb}$ dating horizon, large standard errors in the unsupported ${ }^{210} \mathrm{~Pb}$ concentrations make it difficult to determine variations in sedimentation rates related to these events. Where they occur just below the dating horizon, extrapolation of the ${ }^{210} \mathrm{~Pb}$ chronology becomes very problematic. Because of the slow accumulation rates at the MOLAR sites, an er- 
ror of $1 \mathrm{~cm}$ due e.g. to an inwash event will on average cause a dating uncertainty of about 20 years. Sites where such changes occur include Terianske, Hagelsee, Ledvicah, and to a lesser extent, Gosenköllesee.

\section{CONCLUSION}

Histories of sedimentation rates for all seven sites since the mid- $19^{\text {th }}$ century are summarised in figure 5 . Results for sites with relatively uniform accumulation up until the last 30 years or so are shown in figure 5(a). Results for sites with greater irregularities are shown in figure 5(b).

The sedimentation rates shown for Øvre Neådalsvatn (Fig. 5(a)) are the detailed values given directly by the CRS model calculations. In spite of the small irregular fluctuations shown in this diagram, differences between dates calculated directly from the CRS model and those calculated from the mean sedimentation rate are insignificant. The robustness of these results suggest that it is unlikely there are significant errors in the ${ }^{210} \mathrm{~Pb}$ dates at sites where sedimentation rates have been uniform, or where changes in sedimentation rates have only occurred during the past few decades and been validated by independent stratigraphic dates. These include Øvre Neådalsvatn, Saanajärvi, Gossenköllesee, and Redó. Since none of these sites (apart possibly from Gossenköllesee) have major changes in dry bulk density in the early 19th century, reasonable confidence can also be placed in the extrapolated dates back to 1781 .

Results for the sites shown in figure 5(b) (Terianske, Hagelsee, Ledvicah) are more problematic. The recent chronology at these sites is relatively secure because of the good ${ }^{137} \mathrm{Cs} /{ }^{241} \mathrm{Am}$ stratigraphic dates. The older dates are however less certain. The general pattern at these sites appears to be one in which short episodes of rapid accumulation are superimposed on longer periods of slow stable accumulation. Because the periods of normal accumulation span relatively short sections of the core, it is not possible to calculate sedimentation rates in the older sections with a high degree of confidence. The uncertainties are exacerbated by fluctuations in dry bulk density.

One method of assessing the overall reliability of the results from these latter sites is to compare the tabulated results with the $99 \%$ equilibrium depth, defined as the average depth at which the two simple ${ }^{210} \mathrm{~Pb}$ dating parameters (concentrations and cumulative inventories) reach $99 \%$ equilibrium. It is a relatively robust measure of the depth corresponding to 148 years accumulation and dated 1848 in these cores. Values of the $99 \%$ equilibrium depths do not differ from the 1848 depths given in tables $2-8$ by more than $11 \%$, and the mean deviation for all 7 sites is just 5\%. This suggests that in spite of the various uncertainties, gross errors at these sites are unlikely.

\section{ACKNOWLEDGMENTS}

This work is has been undertaken in the framework of the MOLAR research project funded by the European Commission, Environment and Climate Programme, Contract $\mathrm{N}^{\circ}$ ENV4-CT95-0007. It rests on the work of many colleagues in the MOLAR project and all their contributions are gratefully acknowledged.

\section{REFERENCES}

Agusti-Panareda, A. \& R. Thompson. (2000). Retrodiction of air temperature at eleven remote alpine and arctic lakes in Europe from 1781-1997 AD. J. Paleolimnol.: (in press).

Appleby, P.G. 1998. Dating recent sediments by ${ }^{210} \mathrm{~Pb}$ : Problems and solutions. Proc. 2nd NKS/EKO-1 Seminar, Helsinki, 2-4 April 1997, STUK, Helsinki: 7-24.

Appleby, P.G. (2000). Chronostratigraphic techniques in recent sediments. In: W.M. Last \& J.P.Smol (Eds), Developments in Paleoenvironmental Research. Volume 1, Tracking Environmental Changes in Lake Sediments: Physical and Chemical Techniques. Kluwer: (in press).

Appleby, P.G., P.J. Nolan, D.W. Gifford, M.J. Godfrey, F. Oldfield, N.J. Anderson \& R.W. Battarbee. 1986. ${ }^{210} \mathrm{~Pb}$ dating by low background gamma counting. Hydrobiologia, 141: 21-27.

Appleby, P.G. \& F. Oldfield. 1978. The calculation of ${ }^{210} \mathrm{~Pb}$ dates assuming a constant rate of supply of unsupported ${ }^{210} \mathrm{~Pb}$ to the sediment. Catena, 5: 1-8.

Appleby, P.G. \& F. Oldfield. 1983. The assessment of ${ }^{210} \mathrm{~Pb}$ data from sites with varying sediment accumulation rates. Hydrobiologia, 103: 29-35.

Appleby, P.G., N. Richardson \& P.J. Nolan. 1991. ${ }^{241}$ Am dating of lake sediments. Hydrobiologia, 214: 35-42.

Appleby, P.G., N. Richardson \& P.J. Nolan. 1992. Self-absorption corrections for well-type germanium detectors. Nucl. Inst.\& Methods B, 71: 228-233.

Battarbee, R.W., J-A. Grytnes, J. Catalan, R. Thompson, P.G. Appleby, A. Korhola, H.J.B. Birks \& A. Lami. (2000). Climate variability and ecosystem dynamics at remote Alpine and Arctic lakes: the last 200 years. J. Paleolimnol.: (in press).

Brancelj, A., M. Šiško, G. Muri, C. Kamenik, P.G. Appleby, A. Lami, E. Shilland, N.L. Rose, S.J. Brooks, J.A. Dearing. (2000). Lake Jezero v Ledvici (NW Slovenia) - impacts of earthquakes and climate change to the lake ecosystem. J. Paleolimnol.: (in press).

Goldberg, E.D. 1963. Geochronology with ${ }^{210} \mathrm{~Pb}$. In: Radioactive Dating. I.A.E.A., Vienna: 121-131.

Krishnaswami, S., D. Lal, J.M. Martin \& M. Meybeck. 1971. Geochronology of lake sediments. Earth Planet. Sci. Lett., 11: 407-414.

Lotter, A.F., P.G. Appleby, J.A. Dearing, J.-A. Gryntes, W. Hofmann, C. Kamenik, A. Lami, D.M. Livingstone, C. Ohlendorf, N. Rose \& M. Sturm. (2000). The sediment record of the past 200 years in a Swiss high-alpine lake: Hagelseewli (2339 m a.s.1.) J. Paleolimnol.: (in press).

Oldfield, F. \& P.G. Appleby. 1984. Empirical testing of ${ }^{210} \mathrm{~Pb}$ dating models. In: E.Y. Haworth \& J.G. Lund (Eds), Lake Sediments and Environmental History. Leicester Univ. Press: 93-124.

Oldfield, F., P.G. Appleby \& R. Thompson. 1980. Palaeoecological studies of lakes in the Highlands of Papua New Guinea. I. The chronology of sedimentation. J. Ecology, 68: 457-477.

Pennington, W., R.S. Cambray \& E.M. Fisher. 1973. Observations on lake sediments using fallout ${ }^{137} \mathrm{Cs}$ as a tracer. Nature, 242: 324-326. 
Robbins, J.A. 1978. Geochemical and geophysical applications of radioactive lead. In: J.O. Nriagu (Ed.), Biogeochemistry of Lead in the Environment. Elsevier Scientific, Amsterdam: 285-393.

Thompson, R. \& R.M. Clark. 1989. Sequence slotting for stratigraphic correlation between cores: theory and practice. J. Paleolimnol., 2: 173-184.
Wathne, B.M., S. T. Patrick, D. Monteith \& H. Barth (Eds). 1995. AL:PE 1 Report for the period April 1991-April 1993. European Commission DGXII, Luxembourg: 292 pp. 